\title{
The Gender Earnings Gap inside a Russian Firm: First Evidence from Personnel Data - 1997 to $2002^{+}$
}

\author{
Thomas Dohmen \\ ROA, Maastricht University; IZA and DIW \\ Hartmut Lehmann* \\ DARRT, University of Bologna; IZA; CERT, WDI and DIW \\ Anzelika Zaiceva \\ DARRT, University of Bologna and IZA
}

April 2008

\begin{abstract}
Using unique personnel data from one Russian firm for the years 1997 to 2002 we study the size, development and determinants of the gender earnings gap in an internal labor market during late transition. The gap is sizable but declines strongly over the entire period. Gender earnings differentials are largest for production workers who constitute the largest employee group in the firm. Various decompositions show that these differentials and their dynamics remain largely unexplained by observable characteristics at the mean and across the wage distribution. Our analysis also reveals that the earnings differentials for production workers largely stem from job assignment, as women are predominately assigned to lower paid jobs. Earnings gaps within job levels are small and almost fully explained by observed characteristics.
\end{abstract}

Key words: Gender earnings gap, personnel data, internal labor market, Russia JEL classification: J16, M52, P23.

\footnotetext{
${ }^{+}$We thank Melanie Arntz, Olaf Hübler, Alexander Muravyev, Tiziano Razzolini, two anonymous referees and seminar audiences at IZA in January 2008, at the ESCIRRU workshop in February 2008 in Berlin and at the DFG workshop in March 2008 in Mannheim for very useful comments, suggestions and discussions. We also thank Yuriy Gorodnichenko and Klara Sabirianova Peter for providing us with their Stata routine of the Machado-Mata methodology of wage decompositions.

The authors are grateful to the Deutsche Forschungsgemeinschaft for financial support within the priority programme “Flexibilisierungspotentiale bei heterogenen Arbeitsmärkten” (DFGSP1169). Lehmann also acknowledges the financial support of the European Commission provided within the project "Economic and Social Consequences of Industrial Restructuring in Russia and Ukraine" (ESCIRRU).

* Corresponding author: hartmut.lehmann@unibo.it
} 


\section{Introduction}

Research on the gender wage gap in labor markets in transition is part of a more general agenda that focuses on the question whether transition has brought a worsening of women's position in the labor market or whether they have benefited from the liberalization of the economic system. In this paper, we analyze the size, development, and the determinants of the gender earnings gap within a large Russian firm.

In Soviet times gender equality was one of the tenets of the regime’s ideology. Labor market participation of women was high and discrimination in pay formally absent. However, socialist reality was somewhat less rosy for women as they were confronted with the difficult task to combine work in the household with the job in the enterprise and as they found themselves predominantly in "female" occupations that commanded lower wages. Occupational segregation thus led to the existence of a gender wage gap under socialism, part of which was unexplained by observed productivity characteristics (Malceva and Roshchin, 2006).

With the onset of transition from a centrally planned to a market economy the socio-economic structures in Russia have seen dramatic changes that had more pronounced effects for women: a collapsing welfare system and the substantial reduction in child care facilities were accompanied by a sharp increase in open unemployment, but also the possibility to specialize in home production as an alternative to market work for the first time in generations. In addition, the restructuring of many privatized enterprises and the increase in competition in product markets through trade liberalization as well as the entry of de novo private firms had a profound impact on developments in the Russian labor market. For the most part, these developments have changed the situation of women for the worse; in particular they have drastically reduced life-long employment opportunities in large firms and 
have made labor market attachment for women in general more tenuous. This overall change in women's position in the Russian labor market needs to be kept in mind when analyzing the issue of gender earnings differentials in that country.

One strand of the literature on the gender wage gap (GWG) in transition countries compares the GWG just before the transition to the gap in the early years of transition. In this literature, the initial regime switch is perceived as a quasi-natural experiment that presumably enables researchers to establish a causal effect of transition on the gender wage gap in former Socialist economies. As stressed by Jurajda (2005) and Brainerd (2000), there are above all three forces simultaneously determining the dynamics of the GWG pre-and post-transition. On the one hand, a dramatic widening of the wage distribution, as happened for example in Russia and Ukraine, can increase the gap since women are predominately located in the lower part of the wage distribution (Brainerd, 2000). On the other hand, if low skilled women leave the employment state on a large scale, as was observed for East Germany by Hunt (2002) and for Slovenia by Orazem and Vodopivec (2000), and if this effect dominates, the gap can be reduced. A second determinant potentially lowering the wage gap after the regime switch are increasing returns to educational attainment and other productivity characteristics after liberalization of the labor market. Brainerd (2000) provides convincing evidence that these higher returns reduce the GWG in several Central European transition countries since their female work forces are on average better educated than their male counterparts.

The few studies, which are specifically about gender differentials in the Russian labor market, all use household survey data. In contrast to Brainerd's results, Reilly (1999) finds a stable monthly earnings differential of about 37 percent - and an hourly wage gap of roughly 25 percent - for the years 1992 to 1996 . He establishes, though, that the "unexplained" part rises over the reported period. The research by 
Ogloblin (1999), also covering the early years of the Russian transition (1994 to 1996), suggests that occupational segregation explains most of the gender wage gap. Using panel data, the study by Kazakova (2007) covers a more mature stage of the Russian transition and, using a panel with full wage data, finds that the GWG decreases from 35 percent in 1996 to 16 percent in 2002.

Our paper employs personnel panel data of a large Russian manufacturing firm and analyzes the gender earnings gap (GEG) within this firm for the years 1997 to 2002. ${ }^{1}$ This is the first study not only for Russia, but for any transition economy that uses personnel data to look at gender differentials within a firm. Our analysis of gender differentials with the help of personnel data contributes in several ways to the literature on gender discrimination in transition economies in general, and in Russia in particular.

First, we can establish whether the substantial Russian earnings gap that researchers find with household level data "survives” when we look at the internal labor market of a large Russian firm. It could well be that most of the earnings gap observed with household data comes about because of productivity differences between men and women and their sorting into high- and low-paying firms (Kremer, 1993). Our estimates of the gender earnings gap inside the firm are very similar to estimates of the gender earnings gap obtained from household data. Second, we explore changes in the gender earnings gap. Again, we find that the development of the gender earnings gap at the firm level mirrors the economy-wide development of the gender earnings gap in the Russia: In line with the results of Kazakova (2007) we establish a large reduction in the gender differential from around 38 to 18 percent. Third, given that the earnings differential "survives" within a large privatized firm like ours - one should keep in mind that a large fraction of the Russian workforce is

\footnotetext{
${ }^{1}$ We look at the gender earnings gap and not at the gender wage gap because we do not have precise information on hours worked in our data.
} 
still employed in such firms - we investigate at the mean and over the entire distribution how much of the differential is explained by observed characteristics. Fourth, we test several hypotheses about the determinants of the unexplained part of the gap. For example, we test whether women are willing to receive lower wages in return for larger bonuses, whether female employees are willing to trade off wages for employment security, or whether segregation of women within the firm into low job levels provides an explanation for the gap. ${ }^{2}$ Finally, we investigate the determinants of the gender earnings gap and changes therein. Employing methods introduced by Juhn, Murphy and Pierce (1991) and Machado and Mata (2005) we explore various factors influencing changes in gender differentials cited above, namely changes in earnings inequality, changes in the composition of the workforce and changes in the rewards to productivity characteristics. While the exploration at the means provides some new insights about the causes of the reduction in the gender gap, the analysis across the entire distributions is new for Russia and of particular interest as it shows that the driving force behind the reduction in the earnings gap are brought about by changes in the lower part of the earnings distributions.

The analysis of the gender earnings gap with the help of personnel data can be considered an important complementary exercise also for methodological reasons. Recent work with matched employer-employee data for Western economies has shown that firm specific effects constitute an important determinant of gender differentials (see e.g. the evidence for the United States by Bayard et al., 2003, and for Germany by Heinze and Wolf, 2006 and 2007). If one is unable to control for segregation at the level of the establishment, as is the case with household survey data, one overstates the role of occupational and/or sector segregation in the economy. Using matched data one can provide evidence of within-establishment and within-

\footnotetext{
${ }^{2}$ Ransom and Oaxaca (2005) find that such segregation in a regional grocery chain in the United States goes a long way in explaining the earnings gap.
} 
occupation segregation. The use of such data might also reduce the bias from unobserved heterogeneity by focusing on selected samples of more homogeneous groups of workers (Kunze, 2008). Employing personnel data in the analysis of the GEG might have the advantage of reducing unobserved heterogeneity to a greater degree than can be done with other types of data because of the likely more homogeneous nature of the workforce within one particular firm. With personnel data it is also better possible, as Kunze (2008) notes, to "more credibly investigate whether wage gaps still exist when job characteristics and rank are controlled for.” While personnel data from one firm can never be truly representative of a sector or the economy at large it permits us to explore internal labor markets in large organizations from a gender perspective and pin down those factors that contribute to differential treatment of men and women within such organizations. Due to data scarcity only few studies on the gender gap within large firms exist; however, their results certainly shed additional light on the causes of gender differentials. For example, Barnet-Verzat and Wolff (2008) analyze personnel data on executives of a French firm and document that the GEG is rather small, ranging from 2 to 5 percent over the entire distribution, once hierarchical levels are controlled for, but they do find evidence of a “glass ceiling” effect. ${ }^{3}$

Data scarcity has made it difficult for economists to test implications for the gender earnings gap that derive from theoretical approaches. Two models come especially to mind. Lazear and Rosen (1990) assume that women have a higher expected value of time spent at home which implies that they have a higher separation probability and require a higher ability threshold in order to be promoted. Two important predictions arise from this model: promotion rates (and thus wages) do not differ by gender at very high levels of ability, and female wages on average are lower

\footnotetext{
${ }^{3}$ See also Ransom and Oaxaca (2005) for gender differences in pay, mobility and promotion opportunities within a U.S. firm and Jones and Makepeace (1996) for evidence from a U.K. firm.
} 
within a firm since they are underrepresented in high-paying jobs. Booth, Francesconi and Frank (2003) moot that even if women are promoted in the same numbers as men, this might not automatically attenuate the gender earnings gap. If women have lower market opportunities outside the firm upon promotion, they might be promoted to the same degree or might even have a higher promotion rate, but they receive lower wage increases than men after promotion has occurred. Since we can identify managers in our firm, i.e. high ability employees, we can provide an additional data point to test the predictions of these two models, albeit in a partial fashion.

The remainder of the paper is organized as follows: The next section briefly describes the firm: the position in its product market, the ownership structure as well as its wage and employment policies. Section 3 describes the personnel data, measurement issues connected to gender differentials. Section 4 introduces the methods used to analyze them. Section 5 presents the results in three parts. First, we describe the gender earnings gaps and their decompositions in explained and unexplained parts at the means and across the distributions. Then we explore the various determinants of the gaps, which we enumerated above. A third part looks at changes in the gaps and which of the above cited factors can help explain these changes. A final section provides some tentative conclusions.

\section{The firm and its wage and employment determination}

The particular firm, for which we have data, is located in a provincial city in Russia and operates in the sector "machine building and metal works." After having converted production lines from Soviet times “nearly one hundred percent”, according to the director general of the firm $(\mathrm{CEO})^{4}$, it produces well equipment for gas and oil production and smith-press equipment. More than ninety percent of its production is

\footnotetext{
${ }^{4}$ Source: First interview with the director general of the firm in the spring of 2002.
} 
destined for the Russian market. It has locally no competitors, but nationally it has to compete with more than 5 firms, among them firms from the European Union that export oil equipment to Russia. Nevertheless, being a supplier for the Russian oil industry it has been benefiting from the continuous robust growth, which this industry has experienced since the aftermath of the financial crisis. ${ }^{5}$ At any rate, real output, capacity utilization and profits were all at a trough in 1998, recovered slightly in 1999 and then took off dramatically after the year $2000 .^{6}$

How representative is this firm as far as the sector "machine building and metal works" and Russian industry at large is concerned? Many privatized large firms in the sector and in Russian industry were shedding labor while our firm slightly increased its workforce over the reported period. The CEO is considered one of the successful managers in Russian industry as he early on in the transition initiated the conversion of production from military hardware to equipment serving the Russian oil industry. In our opinion, therefore, this firm is representative of a numerically maybe small but economically important number of industrial firms that have managed the transition to a market-based economy well and that are leaders in their sectors with a brighter future than the average large privatized Russian industrial firm.

\footnotetext{
${ }^{5}$ During the financial crisis and in its aftermath, we observe the following monthly inflation rates: August '98 19\%, September '98 39\%, October '98 5\% and April '99 3\%. Using the standard definition that we speak of hyperinflation when the monthly inflation exceeds 50 percent, it is clear that we cannot speak of a hyperinflationary episode in the Russian economy in 1998 and 1999. Moreover, there is a rapid decline of monthly rates.

6 Some additional remarks about the economic environment, in which the firm operates, are in order. The years 1997 to 2002 include the financial crisis of August 1998 when the ruble was drastically devalued and Russia defaulted on its debt. For our purposes, the crisis is insofar important as it marks a hiatus in the Russian transition process. Before the crisis we have a period of great turmoil and excessive turnover in the labor market, with a large fraction of the workforce experiencing wage arrears and being forced to take unpaid leave (Lehmann, Wadsworth and Acquisti, 1999, and Earle and Sabiarianova, 2002). In the aftermath of the crisis, robust growth started to lift the Russian economy out of its trough, to raise productivity and wages and to reduce the extent and incidence of wage arrears. While the financial crisis had some severe consequences in the form of an upsurge in inflation and a collapse of a large part of the private banking sector, these consequences were very short-term and had little influence on the real economy. We also should stress that the short-lived nature of the crisis prevented the inflationary upsurge in August and September 1998 to be transformed into persistent inflationary pressures and that the crisis did not lead to a major reallocation of resources employed by the economy. In actual fact, in our firm but also in many other firms in industry we observe an increase in the capacity utilization of existing resources (Kapeliushnikov, 2005).
} 
The employees in this firm do not seem to influence wage and employment determination in ways that can partially shape gender earnings gaps within Russian firms. Employees could have this influence above all through two routes. First, corporate governance structures related to privatization and the distribution of shares have an impact on the process of how wages and employment are determined. The firm was founded in the early fifties of the last century and privatized in 1992. A decade later, in 2002, more than half of the shares were owned by managers and employees still working in the firm. From published annual financial statements we, however, know that employees with shares have no voting rights and that the CEO and a few leading managers have a large enough chunk of voting shares to dominate all aspects of firm decision making, including wage and employment policies. There is also the possibility that large dividend payments, paid to a subset of employees and varying over time, could cause differential wage payments across the workforce. However, from the same published statements of the firm we can infer that annual dividend payments to employees are miniscule relative to annual total compensation. In essence, corporate governance structures in this firm neither give employees some direct influence over the wage setting process nor do they confound the levels and the differentiation of wages.

Second, labor market institutions, in particular collective wage bargaining, might have a big impact on wage levels and wage differentials. So, how important are trade unions in this firm? From a second interview with the CEO that took place in April 2007 and from discussions with the director of human resources taking place earlier we can gather that, while there is collective bargaining at the firm on paper, trade union representatives have virtually no influence on wage policy. ${ }^{7}$

\footnotetext{
${ }^{7}$ That employees as share holders or through their trade union lack influence over wage setting can, for example, imply that discrimination against females based on employees' tastes (Becker, 1957) does not come into play in this firm.
} 
Our discussion consequently implies that wages are set unilaterally by top management, which is, however, influenced in its wage policies by local labor market conditions and the need to keep worker turnover at optimizing levels (Dohmen, Lehmann and Schaffer, 2007). Given the dominance of top management it seems, therefore, only natural to directly ask the CEO how he sees the wage determination process. When asked what determines wages, the CEO pointed to the following determinants: (a) qualification of the employee; (b) work tenure/seniority and experience; (c) wage level in the region; (d) wage level in the sector; and (e) price of the order, to which worker is assigned. From the CEO’s declaration it transpires that there is no taste for discrimination on the part of this employer and a female employee with the same qualification, tenure and experience as her male counterpart should earn the same wage or receive the same total compensation. As we shall see, this is far from so in this firm.

\section{Data and measurement issues}

We created an electronic file based on records from the personnel archive of the firm, and constructed a year-end panel data set for the years 1997 to 2002. We have records of all employees who were employed at any time during this period, except for top managers whose information is discarded for reasons of confidentiality. The data contain information on individuals’ demographic characteristics such as gender, age, marital status and number of children, on their educational attainment, retraining and other skill enhancement activities before joining the firm and during tenure at the firm. We also know the exact date when each employee started work at the firm as well as his/her complete working history before that date. In addition, we know whether someone worked full-time or part-time as well as a full-week or not. For 
those who separated from the firm we can distinguish between a voluntary quit, transfer to another firm, individual dismissal, group dismissal and retirement.

In Russian firms the workforce is often divided into five employee categories: administration (i.e. management) which we label "managers"; accounting and financial specialists whom we label “accountants"; engineering and technical specialists (including programmers) whom we subsume under the term “engineers”; primary and auxiliary production workers, whom we label "production workers”; and finally, service staff. The distribution of the workforce across these employee categories is shown in table 1 as are the shares of female workers in each category. We should note here that in this firm employees dealing with financial issues, i.e. “accountants”, are apart from 2 persons, all female, which means, of course, that we do not analyze an earnings gap for this type of employee category. It is also worth mentioning that, apart from the declining fraction of female service staff, the shares of female employees remain fairly constant between 1997 and 2002.

For the years 1997 to 2002 we have monthly wages averaged over the year, and information on the three types of bonuses paid to the workforce: (1) a monthly bonus amounting to a fixed percentage of the wage; (2) an extra annual bonus whose level depends on "the results of the year” (i.e. this bonus is a form of profit sharing); (3) an annual bonus labeled “other bonus”. While production workers never receive a monthly bonus, the bonus labeled "other bonus" is paid to production workers only. Wages are reported by the firm as the employee's average monthly wage in rubles for the year (or fraction of the year, if not employed for the full 12 months), with no adjustment for inflation. The monthly bonus is reported as a percentage of the average monthly wage, and the corresponding ruble figure is recovered by applying the percentage to the nominal monthly wage. The other two bonuses are reported in nominal rubles. The inflation rate in Russia during this period was irregular and 
sometimes quite high - the price level more than doubled between the start of the financial crisis in July 1998 and April 1999, and was 0-2\% per month before and after - and so some care is required to construct appropriate deflators. Because nominal average monthly wage and the nominal monthly bonus are averages for the year, they are deflated into 1997 constant rubles using an annual average CPI, i.e., the average price level for the year relative to the average price level in 1997. The other two bonuses are paid around the end of the year, and so these are converted into 1997 constant rubles using the CPI price level for December of the corresponding year, i.e., the December price level in that year relative to the average 1997 price level. ${ }^{8}$ The shares of the monthly total compensation components are presented in table 2 .

The careful approach to generating real earnings sketched above and the fact that the earnings data are taken from the personnel records of the firm lead us to surmise that measurement error is minimal in these earnings data. At any rate, it is highly unlikely that there are systematic differences in the accuracy of the earnings data across the two genders that are responsible for the estimated gender earnings differentials.

Among the firm's workforce, production workers are subdivided into levels, primary production workers having eight and auxiliary production workers having six

\footnotetext{
${ }^{8}$ We have available monthly data on CPI inflation in Russia overall and in the oblast where the firm is located. In this paper we work primarily with average monthly wages, and so we compare average annual inflation in the oblast with national rates. This shows that inflation in the oblast is very similar to national inflation:

$\begin{array}{ccc} & \text { Russia } & \text { Oblast } \\ 1997 & 15.4 & 14.0 \\ 1998 & 38.1 & 38.7 \\ 1999 & 98.6 & 97.9 \\ 2000 & 20.8 & 20.4 \\ 2001 & 21.6 & 19.1 \\ 2002 & 16.0 & 14.5\end{array}$

These indices are based on average monthly price levels calculated using monthly inflation rates. Over the 1997-2002 period the cumulative price indices diverge by less than $3 \%$. Results using wages and bonuses deflated by the national CPI are therefore essentially identical to those using the oblast CPI. We use the former in what follows.
} 
levels. Since we have these levels only for the cross section of 2002, we will perform decompositions for this cross section in order to see whether segregation into levels might be an important driving force of earnings and total compensation gaps in this firm.

In the data set at hand no hours of work are recorded, hence we cannot calculate an hourly wage. The gap that we can identify is thus a gap in monthly wage earnings, most of which could be driven by differences in hours worked. To ensure that the earnings differential does not just reflect differences in hours worked we only include employees who always were full-time employees and worked every week a full week throughout 1997-2002. This leads to the exclusion of 14 percent of the firm's employees from our analysis, but also increases our confidence that the identified earnings gap is not spurious. $^{9}$

\section{Methods}

In order to document and to analyze the firm-level gender earnings gap in a Russian firm, we use well-known decomposition techniques. These decompositions that we perform for mean earnings are standard fare and, therefore, only briefly mentioned. We start with the traditional Oaxaca-Blinder decomposition (Oaxaca, 1973; Blinder, 1973), which relies on estimating separately two Mincerian log earnings equations by gender. As is well known, the Oaxaca-Blinder decomposition is subject to the socalled “index number problem” and requires using either the male or female earnings structure as a non-discriminatory benchmark. To remedy this problem, Neumark (1988) and Oaxaca and Ransom (1994) advocate a pooled model for both genders using a weighted average of the female and male earnings structures.

\footnotetext{
${ }^{9}$ The existence of overtime, which is only indirectly recorded in our data, does not allow us to impute hourly wages.
} 
Decomposing the earnings gap at different quantiles of the earnings distribution using the Oaxaca-Blinder method can produce biased results. ${ }^{10}$ Their methodology is based on the OLS property that mean earnings conditional on average characteristics is equal to unconditional mean earnings, an assumption that does not hold in the context of quantile regression. In order to decompose the gender earnings gap at different quantiles we use the quantile decomposition technique proposed by Machado and Mata (2005). Denote by $Q^{\theta}\left(\ln w^{i} \mid X^{i}\right)$ the $\log$ of earnings of individual $i$ with characteristics $\mathrm{X}$ who leaves behind a fraction $\theta$ of individuals with the same characteristics (Koenker and Basset, 1978). The earnings gap can then be decomposed as follows:

$$
\begin{aligned}
& Q^{\theta}\left(\ln w^{m}\right)-Q^{\theta}\left(\ln w^{f}\right)=\left[Q^{\theta}\left(X^{i m} \hat{\beta}^{m \theta}\right)-Q^{\theta}\left(X^{i f} \hat{\beta}^{m \theta}\right)\right]+ \\
& +\left[Q^{\theta}\left(X^{i f} \hat{\beta}^{m \theta}\right)-Q^{\theta}\left(X^{i f} \hat{\beta}^{f \theta}\right)\right]+\text { residual }
\end{aligned}
$$

The first term on the right-hand-side shows the contribution of the differences in characteristics between males and females to the earnings gap at the quantile $\theta$, and the second term presents the contribution due to differences in coefficients. The residual should disappear asymptotically as the sample is generated randomly. Note also that the usual "index number problem" is present in this decomposition and we use the earnings structure of males as a non-discriminatory benchmark.

Practical implementation of this decomposition requires making $\mathrm{B}$ independent random draws of percentiles $\theta$ and estimating $\mathrm{B}$ quantile regressions (here $\mathrm{B}=10,000$ ) for each percentile $\theta$ and for males and females separately: $Q^{\theta}\left(\ln w^{i} \mid X^{i}\right)=X^{i} \beta^{\theta}$. Then, a random sample of size B is created from covariates $X$ for each gender. Finally, the counterfactual and actual earnings distributions are generated for different combinations of genders. That is, the counterfactual earnings density $\ln w^{i}=X^{i f} \hat{\beta}^{m \theta}$ shows the log of earnings arising if women had their own

\footnotetext{
${ }^{10}$ See, for example, Felgueroso et al. (2007).
} 
characteristics but were paid as men, while $\ln w^{i}=X^{\text {im }} \hat{\beta}^{f \theta}$ shows a counterfactual earnings density that would arise if females were given males' characteristics but were paid as females. Using the generated coefficients and characteristics, we estimate the earnings gaps at different quantiles of the constructed earnings distributions.

Finally, we also decompose changes in the earnings gap over the period 19972002. First we perform the decompositions at the mean exploiting the well-known methodology originally proposed by Juhn, Murphy and Pierce (1991) and applied by Brainerd (2000) and Reilly (1999) when analyzing changes in the Russian wage gap in the early years of transition. Second, we perform similar decompositions at the quantiles of the earnings distributions, generating intertemporal counterfactuals based on the methodology of Machado and Mata (2005). ${ }^{11}$

\section{Results}

\subsection{The gender earnings gap inside the firm: description}

The aftermath of the financial crisis saw a substantial rise in the consumer price index and a fall in real wages, both across the country and within our firm (Dohmen, Lehmann and Schaffer, 2007). Inspection of figure 1 leads to two obvious conclusions: (1) mean male earnings are larger than their female counterparts, and the mean earnings gap seems to decline as the probability mass linked to higher male earnings is reduced in 2002; (2) the gender-specific earnings distributions for all employees and for workers are shifted to the left over the period 1997 to 2002 and the distributions are more compressed in 2002. ${ }^{12}$ When we will discuss the reasons for the

\footnotetext{
${ }^{11}$ In a transition context, the Machado-Mata (2005) methodology was also employed by Ganguli and Terrell (2005) who analyze the gender wage gap in Ukraine both within years and across time.

${ }^{12}$ The fall in earnings inequality is reflected in falling Gini coefficients of monthly wages and total compensation as shown in Dohmen, Lehmann and Schaffer (2008). The Gini coefficients reported in
} 
decline in the earnings gap below, it will be relevant that inequality falls already in 1998 and that the values of the Gini are always highest for the entire workforce and the employee categories in 1997.

Figure 2 traces the raw GEG for four employee categories and all employees in our firm over the years 1997 to 2002. Recalling that production workers make up roughly two thirds of all employees, it is clear from the figure that their GEG is driving the overall gender earnings differential. Apart from the polar years, engineers have the second highest earnings gap, which is, however, in most years roughly 30 percentage points lower than that of production workers. The earnings gap of service workers exhibits a U-shaped curve, with gaps of roughly 20 percent in 1997 and 2002 but hovering around zero during the rest of the period. Finally, managers have a very small raw gender earnings differential whose adjusted variant is not significant in any year. ${ }^{13}$ This result is in line with the predictions of Lazear and Rosen’s (1990) model that women, once finding themselves in high positions within the same firm, will not experience different treatment from that of men.

The regressions, on which the adjusted gender earnings gaps of figures 3 and 4 are based, are shown for the years 1997 and 2002 in table 3. These regressions point to the determinants of log real earnings at the mean and at several quantiles in the distributions. Apart from the gender dummy, which has a big and highly significant impact throughout, tenure and educational attainment as well as training outside the firm increase earnings, while studying in the firm and within-firm mobility, which is predominantly of a horizontal nature, depress them. Service workers have substantially lower, engineers somewhat lower earnings than production workers, while managers and accountants command an earnings premium on average. Another

that paper corroborate the decline in inequality of monthly wages and total compensation for the entire workforce as well as for the five employee categories in the aftermath of the financial crisis.

${ }^{13}$ The regressions, which generate adjusted gender earnings gaps are not shown here but available on request from the authors. 
specification includes an additional indicator variable which takes the value one for females with children (see columns (2) and (7)). This indicator variable is included in order to allow for a differential treatment of females with children by the tax authorities; but the variable would also pick up mothers’ propensity to trade off more flexible working conditions for lower earnings. For the year 1997 (as well as for the not shown years 1998 to 2001) this dummy is not significant, while in 2002 women with children encounter a wage penalty of 10 percentage points on average. The adjusted earnings gap is lowered by precisely this amount in this year.

The total gender earnings gap in figure 3 rises slightly between 1997 and 1998, when it reaches roughly 40 percent and then falls continuously to the level of around 18 percent in 2002. An Oaxaca-Blinder decomposition ${ }^{14}$ also produces the result that most of the GEG at the mean remains unexplained. The regressions by gender underlying the decompositions at the means as well as quantile regressions by gender at selected quantiles are shown for the years 1997 and 2002 in the appendix (tables A1 and A2). In many instances, they show inter-gender differences in the returns to many of the productivity measures employed in our regressions. To address the concern that the gender earnings gap might above all be a reflection of differences in hours worked, we also perform a "robustness check" by decomposing the GEG for workers using two earnings measures. As stated above, workers receive an "other bonus"; this bonus is paid to workers for additional effort (“completion of work ahead of plan”), but also because of overtime work and work during holidays and days off. The first measure is based on monthly wage earnings alone, while the second one includes in addition the imputed monthly fraction of the "other bonus" that could also reflect differences in productivity in a better way. The two decompositions of the

\footnotetext{
${ }^{14}$ We have also performed Neumark (1988) and Oaxaca-Ransom (1994) decompositions in the earlier version of this paper. In general, the results were very similar to the Oaxaca-Blinder decomposition and we decided to report the latter.
} 
GEG, based on these two measures, are virtually identical. We are thus lead to believe that the GEG is not confounded by differences in hours worked across gender in a major way.

The raw and adjusted earnings gaps across the distribution, shown for the year 1997 in figure 4, are representative for the gaps in the years 1997 to 2001 that are not shown here, i.e., they show large differentials in the lower part of the distribution while in the upper part these differentials decline. Contrary to previous years, the gender earnings gap is increasing over the distribution from close to zero to about 20 percent. ${ }^{15}$ What is also striking from this figure is that the gap is approximately 15-20 percent at the highest quantiles in both years even after having controlled for employee type, which suggests the persistence of the "glass ceiling" effect across years.

Figure 5 and table 4 that reproduce results from Machado-Mata decompositions of the gender earnings differentials across the 1997 and 2002 distributions make the point that differences in returns to characteristics and not characteristics themselves contribute to the GEG across the whole distributions. Note also that while the GEG is lower in 2002 than in 1997, the proportion of the unexplained part is larger in 2002 almost across the whole distribution.

\subsection{The gender earnings gap inside the firm: potential explanations}

Having described the size of the gender earnings gap both at the mean and at various quantiles, and having explored the development of the gender earnings gap over time we now turn to the question of what can explain the gender earnings gap inside our firm? The data that we have at our disposal allow us to look at the following three

\footnotetext{
${ }^{15}$ Results that are based on the specification with the interaction term female-children are very similar to those in figure 4, although the adjusted gap at several quantiles is somewhat lower. These results are not shown here but available on request.
} 
potential explanations: the trade-off between premia and wage earnings, the trade-off between secure jobs and wages and segregation into job levels for workers in the year 2002. Of course, discrimination or selection may also serve as potential reasons.

It is conceivable that as premia make up a substantial part of total earnings, women are willing to accept lower wages in return for larger premia. Comparing figure 6 where we show the Oaxaca-Blinder decomposition of total compensation with the decomposition of wage earnings in figure 3 it is pretty clear, though, that the magnitudes and the evolution over time of the two gaps are pretty similar. Also in both cases most of the gap remains unexplained. A second explanation for different pay for female and male employees with similar observable characteristics could lie in the fact that women trade job security for lower wage earnings. Probit regressions that estimate the probability of quitting or being laid off, which are not shown here, demonstrate, however, that women have a 3 percentage points higher probability to quit and are also slightly more likely to be laid off by the firm, evidence that contradicts the hypothesis of a trade-off between wages and job security.

As shown above, production workers make up the bulk of the firm's workforce and also experience by far the largest gender earnings gap. It is, therefore, worthwhile to take a closer look at the issue whether female workers are segregated into low-paying job levels while men find themselves in levels of higher pay. Unfortunately, currently we have information on levels only for the year 2002 and can only ascertain the position of a production worker in the level structure at the end of the period.

Table 5 provides evidence of female production workers being predominantly confined to the lower job levels in the firm. Nearly all female production workers find themselves in the auxiliary levels. Only in the job level primary 4 can we observe a statistically significant gender earnings gap (in the level primary 5 it is significant at 
the $10 \%$ level), while in all other job levels average pay is the same for female and male production workers. So, women finding themselves in the same job levels as men are for the most part not discriminated against in terms of pay in this firm. The GEG for production workers in 2002 of roughly 30 percent comes, however, about because women have an overwhelmingly lower probability to find themselves in primary job levels even when we control for observable productivity characteristics. This is made abundantly clear in table 6: in the most parsimonious specification women have a probability to be in a primary job level that is 84 percentage points lower than that of their male counterparts. Even women with university education are far less likely to be in a primary job level if they happen to be engaged in production at the shop floor. In addition, the Fairlie decomposition shows that only 11 percent of the difference in the predicted probabilities of being in a primary level is explained by observed characteristics. ${ }^{16}$

Wage earnings and job levels are, of course, highly correlated. This high correlation can be seen when we perform Oaxaca-Blinder decompositions of gender earnings and total compensation gaps. When we condition on job levels, the entire gaps are explained now (table 7). Thus, there is no scope for gender discrimination within a job level. Comparing Machado-Mata decompositions of gender earnings differentials at the quantiles with and without conditioning on job levels leads to the same conclusion: earnings differentials across job levels are large and little of the earnings differential is explained by characteristics, while earnings differentials within job levels are much smaller and virtually entirely explained by observed characteristics at all quantiles (see figure 7). Of course, we are aware of the endogeneity of job levels in the determination of earnings and consequently do not

\footnotetext{
${ }^{16}$ This evidence is consistent with Ransom and Oaxaca (2005) who find that within job levels in a US grocery store men and women are paid the same, but the lower job assignment of women could not be completely explained by individual characteristics.
} 
suggest that job levels have a causal impact on the gender earnings differential. ${ }^{17}$ Nevertheless, our descriptive exercise points to the remarkable fact that there is such a large earnings differential in spite of a seemingly gender neutral wage policy of top management in this firm, which arises because women are in overwhelming numbers placed in low paying job levels (cf. Ransom and Oaxaca, 2005). So far, we only observe the job level of each production workers at the end of the reported period and can thus only point to the high correlation of placement into job levels and gender earnings differentials. In future work, once we have data on the evolution of job levels for each production worker, we will analyze whether there are important gender differences in promotion rates and in entry-level jobs.

\subsection{Changes in the gender earnings gap over time and their potential reasons}

The 20 percentage points decrease in the gender wage gap between 1997 and 2002 is decomposed in table 8 . About 28 percent of the decrease can be explained by observables, with changes in observed characteristics being about four times as important as changes in observed prices. The unobserved factors are nearly of equal importance. About 6 points of the reduction of the gap comes about because women improve their position in the male residual wage distribution while about 8 points are due to a narrowing of this distribution. While this last factor has the most weight, the other factors are jointly more important. ${ }^{18}$ That the rise or fall in inequality has little impact on movements of the gender earnings gap in our firm can also be seen by the above mentioned fact that the gap rose between 1997 and 1998 while inequality fell between the two years.

\footnotetext{
${ }^{17}$ It is possible that the gender difference in occupational distribution partly reflects employment discrimination or unequal occupational access. If it does, then it cannot be used to "explain” the GWG (see, for example, Kidd and Schannon, 1996 and Rodgers, 2006).

${ }^{18}$ In contrast, in the early years of transition when the Russian gender wage gap increased dramatically, Brainerd (2000) finds that the widening of the residual male wage distribution completely overwhelms and cancels out the first three factors that all have a slightly negative impact on the change of the wage differential in the data that she analyzes.
} 
In table 9 we compare the earnings gaps of 2002 and 1997 across the distribution and perform several counterfactual exercises over time, following Ganguli and Terrell (2005). This enables us to document whether changes in the characteristics of men and women or changes in the returns to these characteristics at specific points in the distributions contributed to the fall in the gap between 1997 and 2002. As we can see from row (3) the raw gap fell more at the bottom than at the top of the distribution (see also Figure 4). The first counterfactual, denoted gap 1, asks what the gap would have been if women in 2002 had the characteristics of the female group that we observe in 1997. Row (6) shows that the gap would have fallen at the bottom but would have remained almost the same throughout the rest of the distribution. Hence, women's characteristics at the bottom were better in 1997 than they were in 2002, but this does not hold in the rest of the distribution. The deteriorating characteristics at the bottom do not help us explain the falling gap, though.

The second counterfactual experiment (gap 2) asks what the gap would have looked like if in 2002 the returns to women's characteristics had been those of 1997 (row 7). Under this counterfactual scenario, the gap would have been negative at the top, i.e. women would have fared better than men, and would have risen a lot at the bottom (row 9). Thus a large increase in the “prices” of women's characteristics at the bottom is an explanation of the larger fall of the gender earnings gap at the bottom. We perform the same counterfactual experiments for men. Their results can be briefly summarized as follows. At the $10^{\text {th }}$ decile men's characteristics were slightly better in 1997 than in 2002 and worsening of those characteristics contributed to a fall in the gap to a small extent. Returns to men's characteristics, on the other hand, declined between 1997 and 2002 and contributed to the reduction in the gap throughout the distribution, although this reduction was higher in the upper part. The 
upshot of table 9 is, at any rate, that a substantial increase in the rewards for women's characteristics at the bottom - together with a slight worsening of male characteristics - generates the larger fall of the gender earnings gap in this part of the distribution.

Another candidate behind the evolution of gender earnings gap in Russia pointed out in the literature is wage arrears. Kazakova (2007) and Gerry, Kim and Lee (2004) moot that because of social considerations by firms low paid female employees see an improvement in the payment culture relative to low paid male employees, thus the gap increases. In our firm data, we only have wage arrears at the end of 1998 when they were at a peak. However, relative to the country at large wage arrears were of minor importance in the firm and workers, where we see the largest GEG, actually had on average only 0.05 months of 1997 wages withheld while in the Russian economy the average worker was confronted with a stock of wage arrears amounting to 2 months of 1997 wages (Lehmann and Wadsworth, 2007). Furthermore, Dohmen, Lehmann and Schaffer (2008) find no gender difference in the incidence of wage arrears for all employees, while they find a lower incidence for male production workers and for female engineers. This latter fact helps explain the rise of the earnings gap that we observe in table 10 when we go from the whole workforce to the sub-sample of employees paid in full and the small fall when we proceed in the same way with production workers only. Table 10 also shows similar decomposition results for the entire groups and the sub-samples of those paid in full. It is at any rate clear that the fall over the entire period has nothing to do with wage arrears since after 1999 this firm has no problems in paying all its employees in full and on time.

A falling gender earnings gap could be caused by the withdrawal of poorly qualified and low paid female employees as was demonstrated by Hunt (2002) for former East-Germany. We, therefore, perform probit regressions that estimate the 
probability of separations. Table 11 finds similar results as Dohmen, Lehmann and Schaffer (2008) who estimated the hazard rate from employment using a Cox proportional hazard model. Controlling for a large number of observable characteristics employees who find themselves at the beginning of the reported period in low deciles of the employee category specific earnings distribution have the highest propensity to separate from the firm. However, females finding themselves in the lower part of these distributions are actually less likely to separate from the firm. Thus changes in the composition of the female workforce do not seem to be behind the falling gender earnings gap. We should not that this result also holds in the specification that includes a female-children interaction dummy.

Thus far we have only looked at separations in order to explain the change in the composition of the workforce throughout the distribution. For a complete assessment it is important to also characterize new entrants into the firm. Since we have no information about the population from which these new entrants are drawn we cannot perform regressions that estimate the probability of being hired. Cross tabulations, however, can be used to compare the characteristics of new entrants with the characteristics of incumbents. These tabulations ${ }^{19}$ show that in all years for males and females alike the new entrants have slightly "worse” characteristics (e.g. they are slightly less educated) than the incumbents. We can take this as evidence that the average "quality" of the stock of female employees does not improve over time because of new hires. In addition, the tabulations show that the change in the composition that we stipulate for male employees in the lower part of the distribution is also not driven by hirings.

In summary, the only explanation that seems to hold up comes out of the intertemporal counterfactuals that are based on the Machado-Mata method: male

\footnotetext{
${ }^{19}$ They are not shown here but available upon request.
} 
employees with relatively good characteristics finding themselves in the lowest part of the distribution at the beginning of the period seem to have separated more frequently from the firm. But most importantly, an increase in the rewards to female characteristics, which is particularly prevalent in the lower part of the distribution, seems to be the main driving force behind the falling gender earnings gap.

\section{Conclusions}

We have analyzed the size of the gender earnings gap and its determinants and development over time using data from a large Russian firm. The results show that the estimates of the gender earnings gap at the firm level are very similar in magnitude to estimates of the gender gap in the economy at large. Moreover, the development of the gender earnings differential over time also mirrors developments in the Russian economy. Observed characteristics that are related to individual productivity only explain a small fraction of the gender earnings gap. The narrowing of the gap at the firm level is partly driven by gender differences in separation patterns. In particular, men who are in the lower part of the residual wage distribution but have relatively favorable observed characteristics are more likely to separate, most likely because they face better outside alternatives. Women in the lower end of the wage distribution have lower separation rates. This is likely the result of an increase in the rewards to female characteristics, which is particularly prevalent in the lower part of the distribution. Our estimates indicate that this increase in the rewards for women is the main driving force behind the falling gender earnings gap.

Importantly, our analysis reveals that the gender earnings gap is largely driven by job assignment rather than by earnings differentials within a particular job level. For production workers, we have shown that earnings differentials conditional on the job level are small to start with and almost entirely explained by observed 
characteristics related to productivity. Future work has to clarify whether gender differences in job assignment stem from differences in unobserved productivity differences or from discrimination in initial job assignment or subsequent promotion chances. 


\section{References}

Barnet-Verzat C. and F.-C. Wolff (2007). Gender Wage Gap and the Glass Ceiling Effect: A Firm-Level Investigation. International Journal of Manpower (forthcoming).

Bayard K., J. Hellerstein, D. Neumark and K. Troske (2003). New Evidence on Sex Segregation and Sex Differences in Wages from Matched Employee-Employer Data. Journal of Labor Economics 21 (4): 887-922.

Becker, G.S. (1957). The Economics of Discrimination. Chicago: University of Chicago Press.

Blinder, A.S. (1973). Wage Discrimination: Reduced Form and Structural Variables. Journal of Human Resources 8: 436-55.

Booth, A.L., Francesconi, M. and J. Frank (2003). A Sticky Floors Model of Promotion, Pay and Gender. European Economic Review 47: 295-322.

Brainerd (2000). Women in Transition: Change in Gender Wage Differentials in Eastern Europe and FSU. Industrial and Labour Relations Review 54(1): 139-62.

Dohmen T., H. Lehmann and M. Schaffer (2008). Wage Policies of a Russian Firm and the Financial Crisis of 1998: Evidence from Personnel Data - 1997 to 2002. IZA Discussion Paper No. 3350, February.

Dohmen T., H. Lehmann and M. Schaffer (2007). Wage Determination and Wage Inequality inside a Russian Firm in Late Transition: Evidence from Personnel Data 1997 to 2002. DARRT Working Paper No. 01/07, September.

Earle, J.S. and K. Sabiarianova (2002). How Late to Pay? Understanding Wage Arrears in Russia. Journal of Labor Economics, 20(3), 661-707.

Felgueroso, F., Perez-Villadoniga, M.J. and J. Prieto (2007). Collective Bargaining and the Gender Wage Gap: A Quantile Regression Approach. University of Oviedo Working Paper No. 2007-06.

Ganguli, I. and K. Terrell (2005). Wage Ceilings and Floors: The Gender Gap in Ukraine’s Transition. IZA Discussion Paper No. 1776.

Gerry C.J., B.-Y. Kim and C.A. Li (2004). The Gender Wage Gap and Wage Arrears in Russia: Evidence from the RLMS. Journal of Population Economics 17: 267-88.

Heinze, A. and E. Wolf (2007). Personnel Policy and the GWG within German Firms. Paper presented at the 2007 ESPE Conference, Chicago.

Heinze, A. and E. Wolf (2006). Gender Earnings Gap in German Firms: The Impact of Firm Characteristics and Institutions. ZEW Discussion Paper No. 06-020. 
Hunt, J. (2002). The Transition in East-Germany. When is a Ten Point Fall in the Gender Wage Gap Bad News? Journal of Labour Economics 20(1): 148-69.

Juhn C., K.M. Murphy and B. Pierce (1991). Accounting for the Slowdown in BlackWhite Wage Convergence. In: M. Kosters (ed.) "Workers and Their Wages”, AEI Press, Washington, DC.

Jurajda, Š. (2005). Gender Segregation and Wage Gap: An East-West Comparison, Journal of the European Economic Association 3(2-3): 598-607.

Kapeliushnikov, R. (2005). The Russian labor market. Adaptation without restructuring) (In Russian: Российскии рынок труда: адаптация без реструктуризации). “Еconomica”, Moscow.

Kazakova, I. (2007). Wages in a Growing Russia. When is a 10 per cent Rise in the Gender Wage Gap Good News? Economics of Transition 15 (2): 365-92.

Kidd, M. P. and M. Schannon (1996). Does the Level of Occupational Aggregation Affects the Estimates of the Gender Wage Gap. Industrial and Labor Relations Review 49 (2): 317-29.

Koenker, R. and G. Bassett (1978). Regression Quantiles. Econometrica 46 (1): 3350 .

Kremer, Michael (1993). The O-ring Theory of Economic Development. Quarterly Journal of Economics 108(3): 551-75.

Kunze, A. (in press). Gender Wage Gap Studies: Consistency and Decomposition. Empirical Economics.

Lehmann, H. and J. Wadsworth (2007). Wage Arrears and Inequality in the Distribution of Pay: Lessons from Russia. Research in Labor Economics 26: 125-55.

Lehmann H., J. Wadsworth and A. Acquisti (1999). Grime and Punishment: Insecurity and Wage Arrears in the Russian Federation. Journal of Comparative Economics 27: 595-617.

Machado, J.A.F and J. Mata (2005). Counterfactual Decomposition of Changes in Wage Distributions using Quantile Regression. Journal of Applied Econometrics 20: 445-465.

Malceva, I.O. and S. J. Roshchin (2006). Gender Segregation and Mobility in Russian Labor Market (In Russian: Гендерная сегрегация и мобильность на российском рынке труда). Higher School of Economics Publishing, Moscow, Russia.

Neumark, D. (1988). Employers' Discriminatory Behavior and the Estimation of Wage Discrimination. The Journal of Human Resources 23: 279-295.

Oaxaca, R.L. (1973). Male-Female Wage Differentials in Urban Labour Markets. International Economic Review 14: 693-709. 
Oaxaca, R.L. and M.R. Ransom (1994). On Discrimination and the Decomposition of Wage Differentials. Journal of Econometrics 61: 5-21.

Ogloblin, G. (1999). The Gender Earnings Differential in the Russian Transition Economy. Industrial and Labour Relations Review 52(4): 602-627.

Orazem, P. and M. Vodopivec (2000). Male-Female Differences in Labour Market Outcomes during the Early Transition to Market: The Cases of Estonia and Slovenia. Journal of Population Economics, 13(2): 283-303.

Reilly, B. (1999). The Gender Pay Gap in Russia During the Transition, 1992-96. Economics of Transition 7 (1): 245-64.

Rodgers, W. M. (2006). Handbook on the Economics of Discrimination. Edward Elgar Publishing. 
Figure 1 - Kernel densities of real earnings by gender, 1997 and 2002

All employees

1997

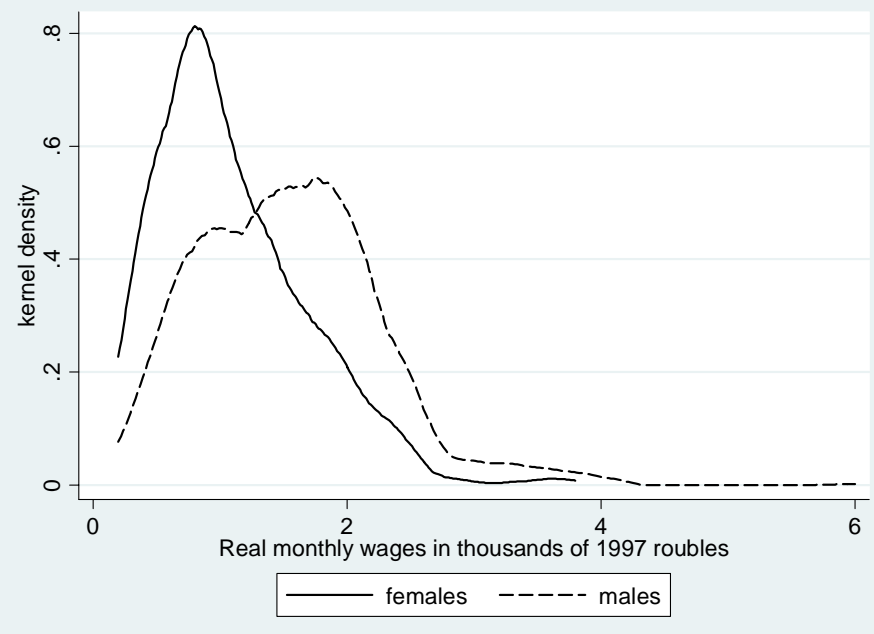

Workers

1997

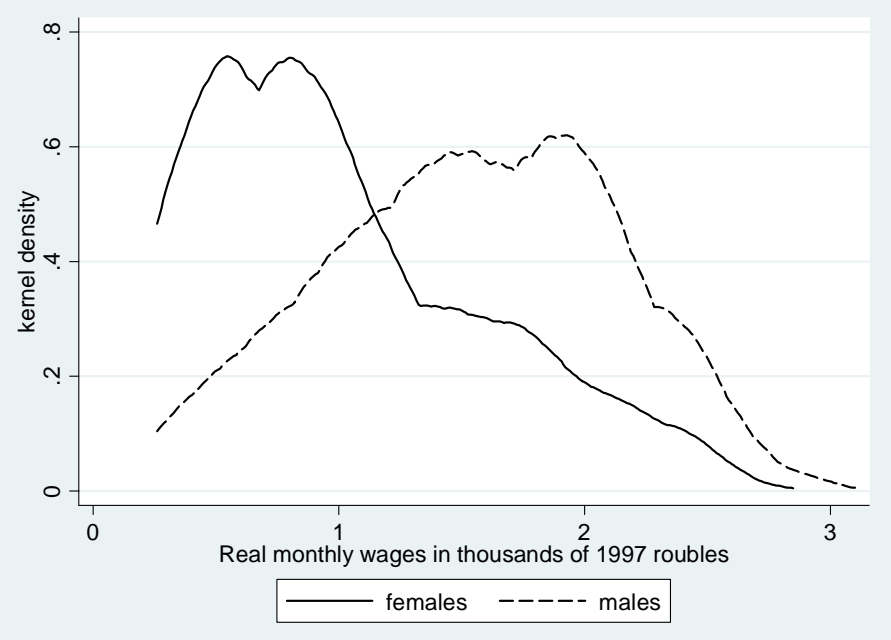

2002

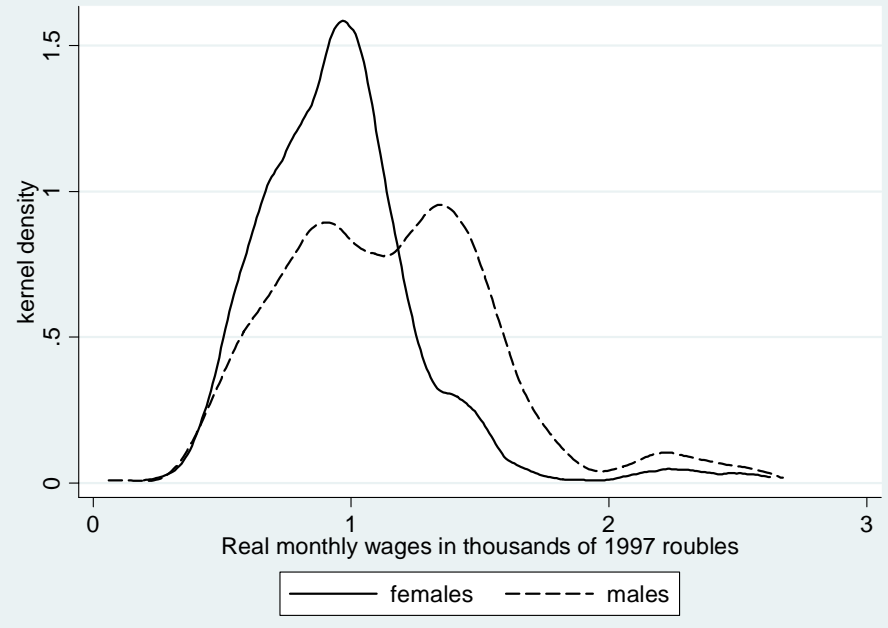

2002

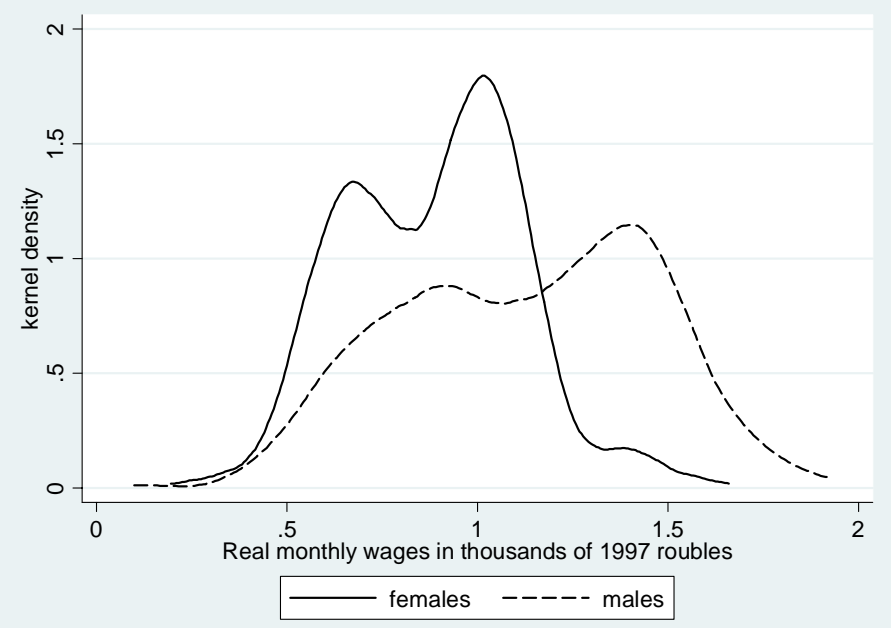

Source: Earnings records form personnel data set. 
Figure 2 - Raw gender earnings gap by employee category

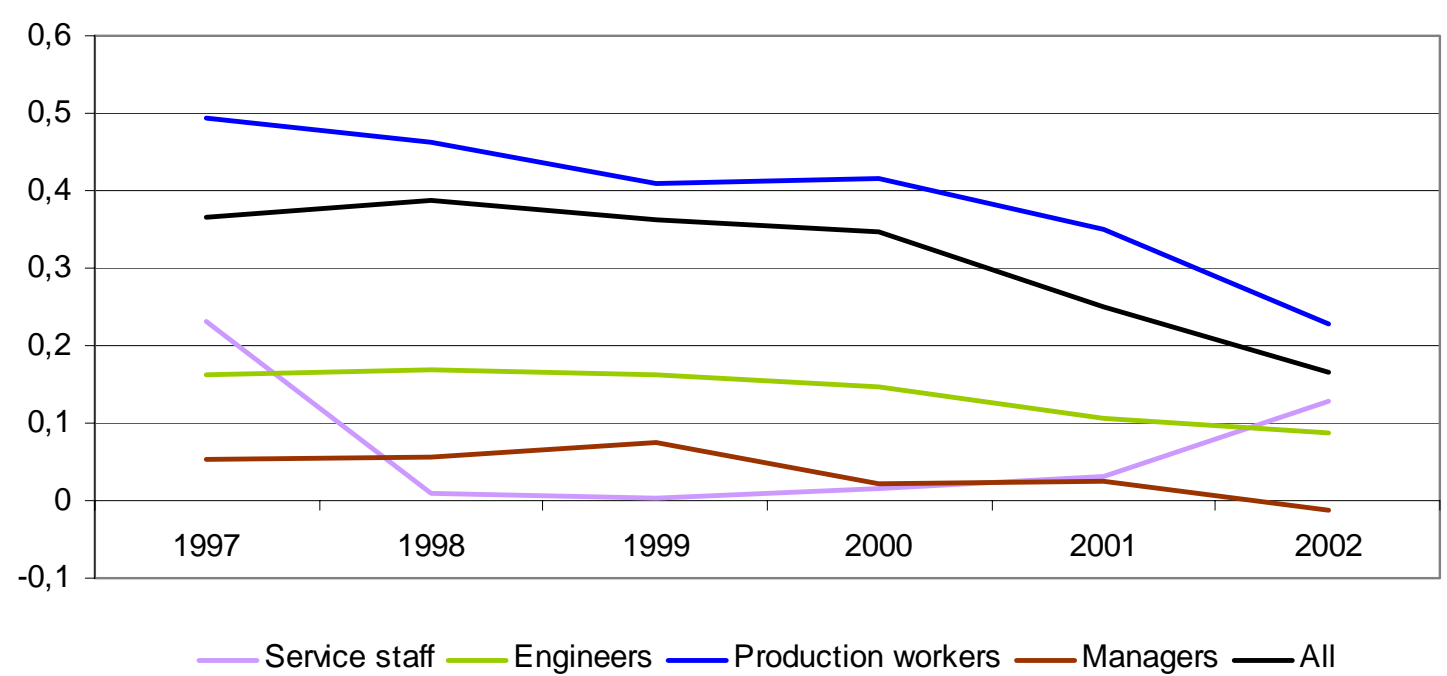

Figure 3 - Oaxaca-Blinder decomposition of gender earnings gap

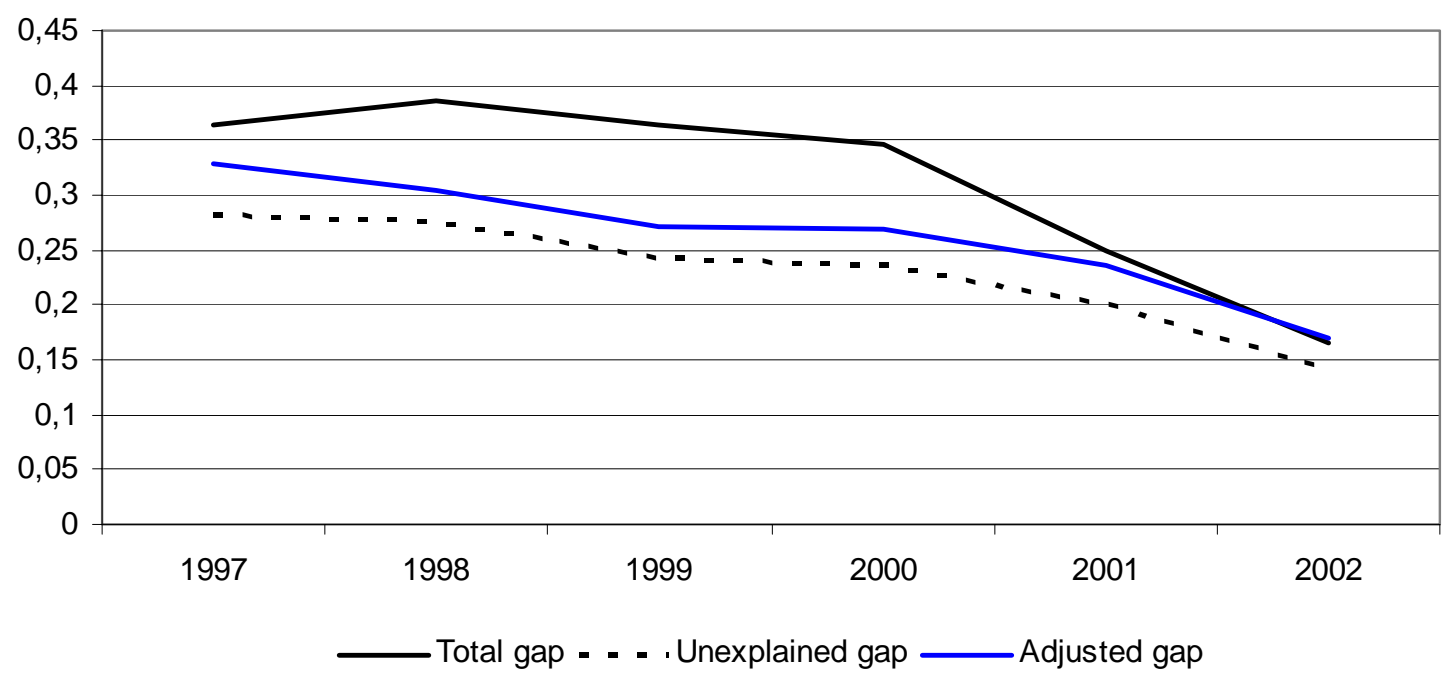

Note: Controls include tenure (its square and cube), age (its square and cube), education dummies, marital status, dummies for having one or more than one child, dummies for training outside firm, internal mobility, within-firm training and employee category dummies. 
Figure 4 - Raw and adjusted earnings gaps at quantiles: 1997 and 2002

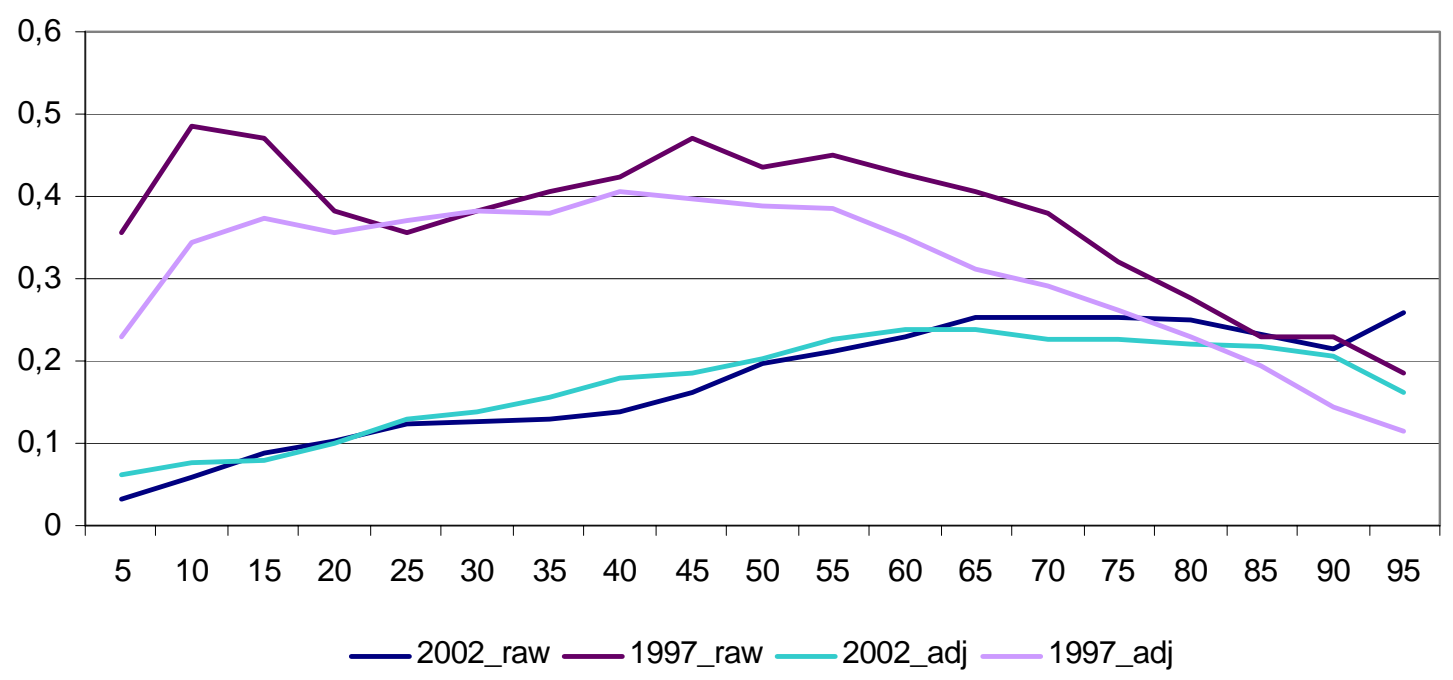

Notes: Coefficient on male dummy is reported from the quantile regressions without and with controls, respectively. Controls include tenure (its square and cube), age (its square and cube), education dummies, marital status, dummies for having one or more than one child, dummies for training outside firm, internal mobility, within-firm training and employee category dummies.

Figure 5 - Machado-Mata earnings gap decompositions at quantiles: 1997 and 2002
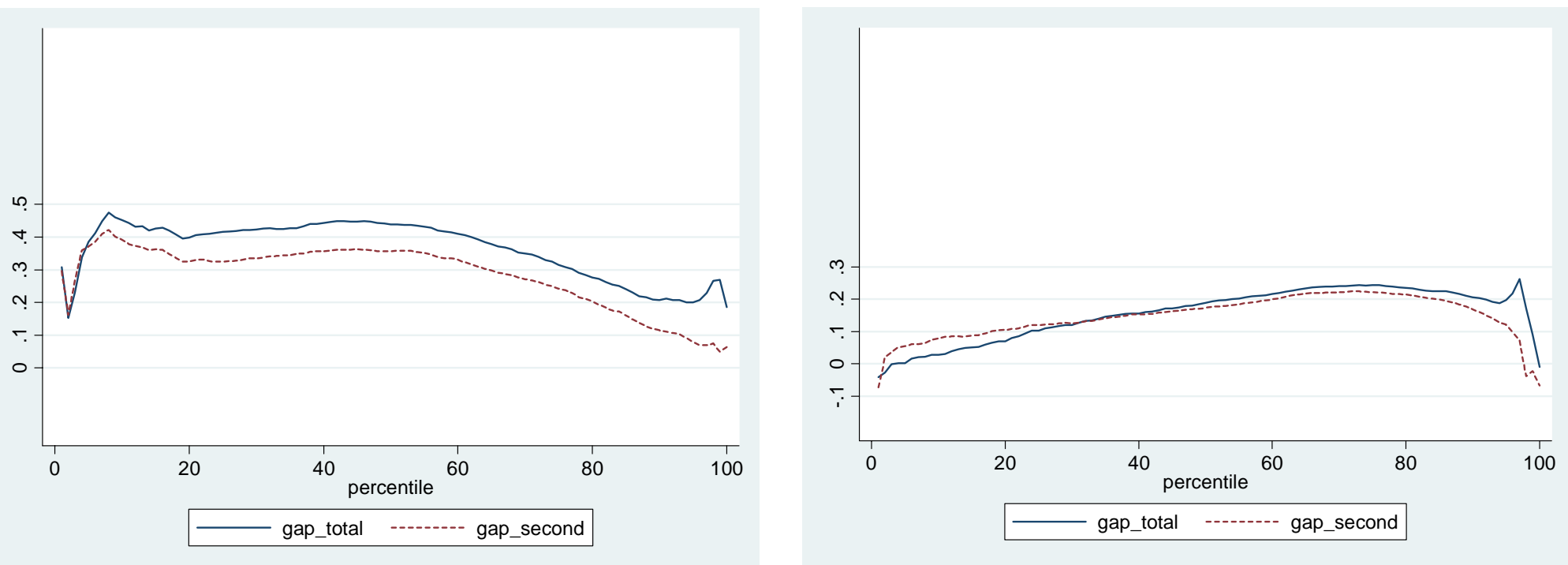
Figure 6 - Oaxaca-Blinder decomposition of gender gap in total compensation: 1997 to 2002

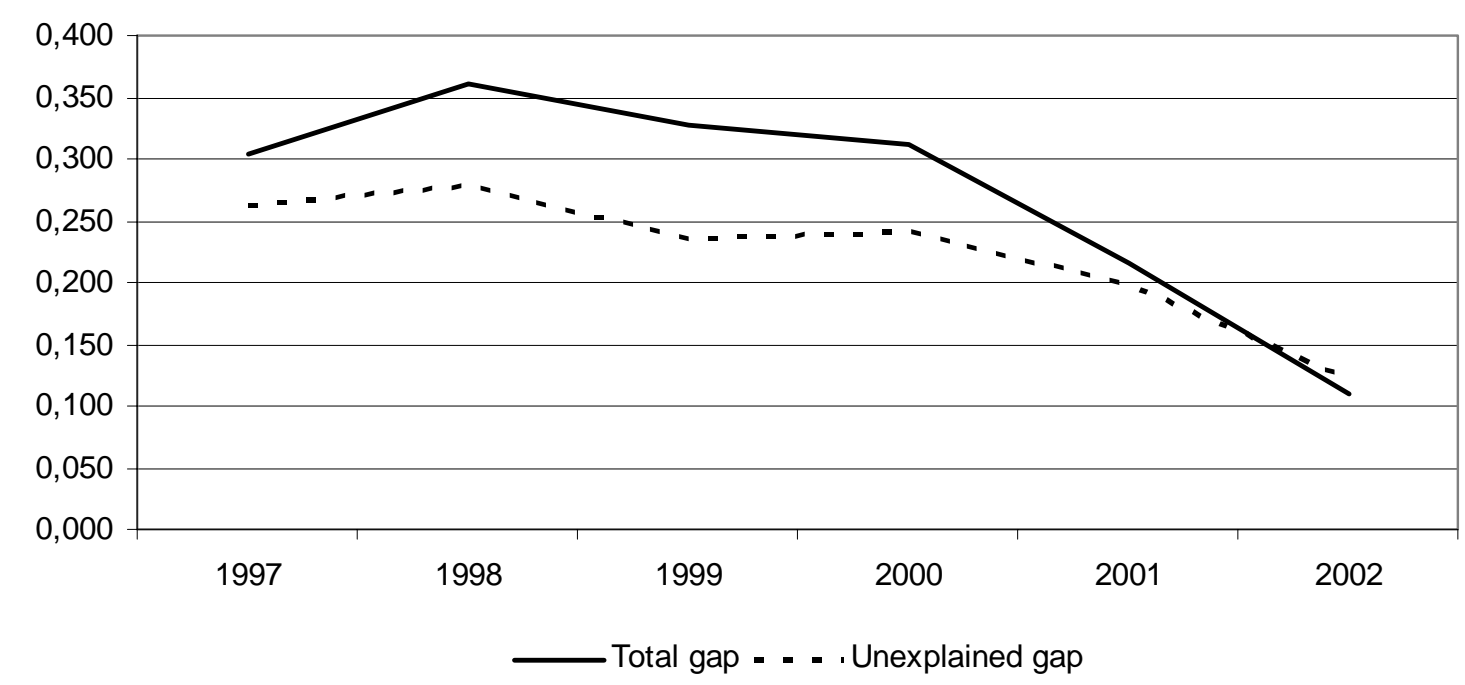

Note: Controls include tenure (its square and cube), age (its square and cube), education dummies, marital status, dummies for having one or more than one child, dummies for training outside firm, internal mobility, within-firm training and employee category dummies.

Figure 7 - Machado-Mata decompositions for workers

Without levels:

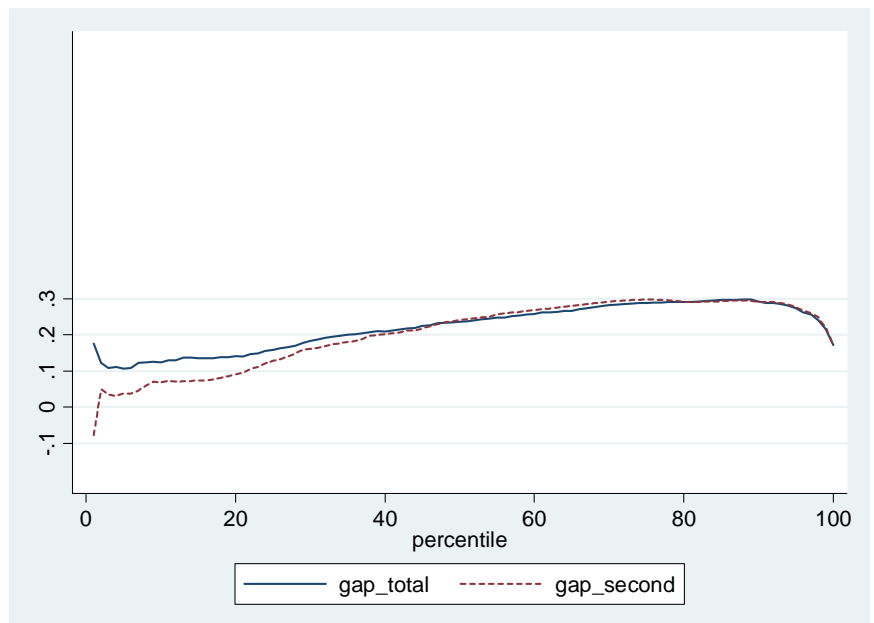

With levels:

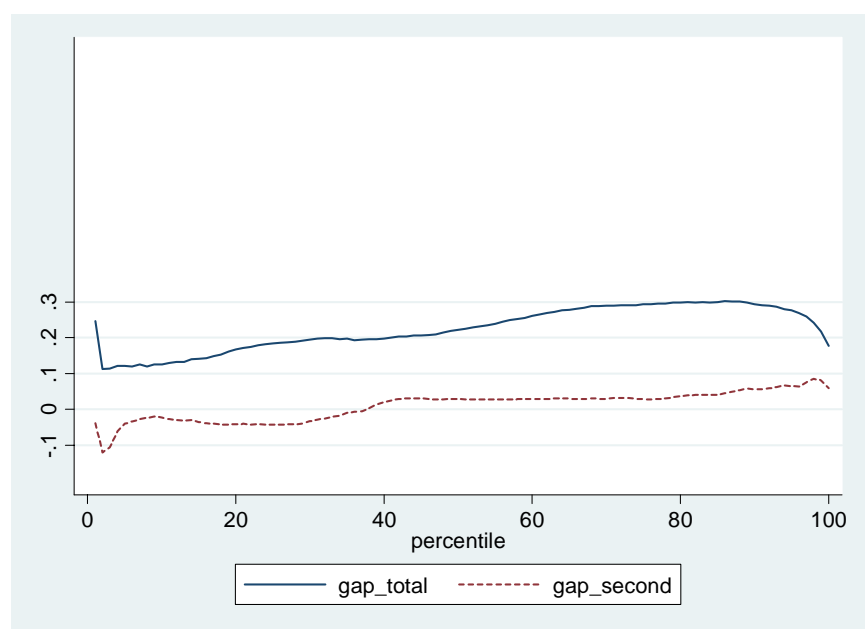




\section{Tables}

Table 1 - Composition of workforce (in \%), 1997 to 2002

\begin{tabular}{|c|c|c|c|c|c|c|c|}
\hline Year & $\begin{array}{c}\text { Service } \\
\text { staff }\end{array}$ & Engineers & $\begin{array}{c}\text { Production } \\
\text { workers }\end{array}$ & Accountants & Managers & Total & $\begin{array}{l}\text { Absolute } \\
\text { number of } \\
\text { employees }\end{array}$ \\
\hline \multirow[t]{2}{*}{1997} & 4.8 & 26.7 & 61.6 & 2.6 & 4.2 & 100 & 2,898 \\
\hline & $(40.7)$ & $(55.0)$ & (30.8) & (97.3) & (17.1) & (38.9) & \\
\hline \multirow[t]{2}{*}{1998} & 4.6 & 26.0 & 62.5 & 2.5 & 4.4 & 100 & 2,937 \\
\hline & (35.3) & (55.0) & (29.1) & $(97.2)$ & (19.2) & (37.4) & \\
\hline \multirow[t]{2}{*}{1999} & 4.8 & 26.7 & 62.1 & 2.3 & 4.2 & 100 & 2,863 \\
\hline & (35.3) & (53.7) & (31.8) & $(97.0)$ & (20.0) & (38.8) & \\
\hline \multirow{2}{*}{2000} & 5.1 & 27.1 & 61.4 & 2.2 & 4.2 & 100 & 2,866 \\
\hline & $(34.2)$ & (54.2) & (30.3) & (96.9) & $(21.0)$ & (38.1) & \\
\hline \multirow[t]{2}{*}{2001} & 5.0 & 26.4 & 62.1 & 2.5 & 4.0 & 100 & 2,962 \\
\hline & $(34.2)$ & (53.5) & (31.0) & (97.3) & $(21.0)$ & (38.3) & \\
\hline \multirow[t]{2}{*}{2002} & 5.2 & 25.7 & 63.1 & 2.2 & 3.9 & 100 & 2,974 \\
\hline & (32.5) & (52.9) & (30.9) & (96.9) & (21.4) & $(37.7)$ & \\
\hline
\end{tabular}

Notes: fulltime, full-week only and non-missing wages and explanatory variables.

Percent in brackets are shares of females in employee category (in\%).

Table 2 - Shares of monthly total compensation components

\begin{tabular}{cccccc}
\hline \hline Year & $\begin{array}{c}\text { Monthly } \\
\text { Wage }\end{array}$ & $\begin{array}{c}\text { Monthly } \\
\text { Bonus }\end{array}$ & $\begin{array}{c}\text { Extra } \\
\text { Bonus }\end{array}$ & $\begin{array}{c}\text { Other } \\
\text { Bonus }\end{array}$ & $\begin{array}{c}\text { Average } \\
\text { monthly } \\
\text { compensation }\end{array}$ \\
\hline 1997 & 0.830 & 0.080 & 0.051 & 0.039 & 1.635 \\
1998 & 0.916 & 0.059 & 0.000 & 0.025 & 1.559 \\
1999 & 0.870 & 0.066 & 0.043 & 0.021 & 1.131 \\
2000 & 0.854 & 0.066 & 0.042 & 0.038 & 1.165 \\
2001 & 0.797 & 0.081 & 0.098 & 0.025 & 1.315 \\
2002 & 0.776 & 0.095 & 0.088 & 0.041 & 1.395 \\
\hline
\end{tabular}

Notes: whole initial sample. Average monthly compensation is given in thousand of 1997 rubles. See text for definitions. 
Table 3 - Determinants of log real earnings: 1997 and 2002

\begin{tabular}{|c|c|c|c|c|c|c|c|c|c|c|}
\hline & $(1)$ & (2) & (3) & $(4)$ & (5) & (6) & (7) & $(8)$ & (9) & (10) \\
\hline & & & 1997 & & & \multicolumn{5}{|c|}{2002} \\
\hline & \multirow{2}{*}{\multicolumn{2}{|c|}{ OLS }} & & atile Regres & & \multirow{2}{*}{\multicolumn{2}{|c|}{ OLS }} & \multicolumn{3}{|c|}{ Quantile Regressions } \\
\hline & & & 10th & 50th & 90th & & & 10th & 50th & 90th \\
\hline Female & $\begin{array}{c}-0.328 * * * \\
(0.021)\end{array}$ & $\begin{array}{c}-0.300 * * * \\
(0.081)\end{array}$ & $\begin{array}{c}-0.344^{* * * *} \\
(0.048)\end{array}$ & $\begin{array}{c}-0.388^{* * * *} \\
(0.020)\end{array}$ & $\begin{array}{c}-0.144^{* * * *} \\
(0.016)\end{array}$ & $\begin{array}{c}-0.170^{* * * *} \\
(0.012)\end{array}$ & $\begin{array}{c}-0.069 * \\
(0.041)\end{array}$ & $\begin{array}{c}-0.076^{* * * *} \\
(0.020)\end{array}$ & $\begin{array}{c}-0.203^{* * * *} \\
(0.013)\end{array}$ & $\begin{array}{c}-0.207 * * * \\
(0.014)\end{array}$ \\
\hline Tenure & $\begin{array}{c}0.029 * * * \\
(0.008)\end{array}$ & $\begin{array}{c}0.029 * * * \\
(0.008)\end{array}$ & $\begin{array}{l}0.033^{*} \\
(0.017)\end{array}$ & $\begin{array}{c}0.029 * * * \\
(0.008)\end{array}$ & $\begin{array}{c}0.026^{* * *} \\
(0.007)\end{array}$ & $\begin{array}{c}0.017 * * * \\
(0.005)\end{array}$ & $\begin{array}{c}0.017^{* * *} \\
(0.005)\end{array}$ & $\begin{array}{c}0.011 \\
(0.008)\end{array}$ & $\begin{array}{c}0.010 * * \\
(0.005)\end{array}$ & $\begin{array}{c}0.006 \\
(0.005)\end{array}$ \\
\hline Tenure squared /100 & $\begin{array}{c}-0.146^{* *} \\
(0.071)\end{array}$ & $\begin{array}{c}-0.146 * * \\
(0.071)\end{array}$ & $\begin{array}{l}-0.116 \\
(0.139)\end{array}$ & $\begin{array}{c}-0.146^{* *} \\
(0.069)\end{array}$ & $\begin{array}{c}-0.158^{* *} \\
(0.064)\end{array}$ & $\begin{array}{c}-0.074 * * \\
(0.037)\end{array}$ & $\begin{array}{c}-0.074 * * \\
(0.037)\end{array}$ & $\begin{array}{c}-0.062 \\
(0.053)\end{array}$ & $\begin{array}{c}-0.023 \\
(0.036)\end{array}$ & $\begin{array}{l}-0.013 \\
(0.039)\end{array}$ \\
\hline Tenure cubed/1000 & $\begin{array}{c}0.028 \\
(0.017)\end{array}$ & $\begin{array}{c}0.027 \\
(0.017)\end{array}$ & $\begin{array}{c}0.017 \\
(0.030)\end{array}$ & $\begin{array}{c}0.025 \\
(0.016)\end{array}$ & $\begin{array}{l}0.029^{*} \\
(0.016)\end{array}$ & $\begin{array}{c}0.014 * * \\
(0.007)\end{array}$ & $\begin{array}{c}0.014^{* *} \\
(0.007)\end{array}$ & $\begin{array}{l}0.017^{*} \\
(0.010)\end{array}$ & $\begin{array}{c}0.003 \\
(0.007)\end{array}$ & $\begin{array}{c}0.002 \\
(0.008)\end{array}$ \\
\hline Age & $\begin{array}{c}0.030 \\
(0.043)\end{array}$ & $\begin{array}{c}0.031 \\
(0.043)\end{array}$ & $\begin{array}{c}0.019 \\
(0.085)\end{array}$ & $\begin{array}{c}0.062 \\
(0.040)\end{array}$ & $\begin{array}{c}0.009 \\
(0.038)\end{array}$ & $\begin{array}{c}0.080 * * * \\
(0.021)\end{array}$ & $\begin{array}{c}0.080 * * * \\
(0.021)\end{array}$ & $\begin{array}{c}0.119 * * * \\
(0.037)\end{array}$ & $\begin{array}{c}0.052^{* *} \\
(0.024)\end{array}$ & $\begin{array}{c}0.055^{* *} \\
(0.023)\end{array}$ \\
\hline Age squared/100 & $\begin{array}{l}-0.015 \\
(0.113)\end{array}$ & $\begin{array}{c}-0.018 \\
(0.114)\end{array}$ & $\begin{array}{c}0.018 \\
(0.230)\end{array}$ & $\begin{array}{c}-0.090 \\
(0.106)\end{array}$ & $\begin{array}{c}0.024 \\
(0.103)\end{array}$ & $\begin{array}{c}-0.176^{* * *} \\
(0.053)\end{array}$ & $\begin{array}{c}-0.176 * * * \\
(0.053)\end{array}$ & $\begin{array}{c}-0.275^{* * * *} \\
(0.092)\end{array}$ & $\begin{array}{c}-0.101^{*} \\
(0.060)\end{array}$ & $\begin{array}{c}-0.118^{* *} \\
(0.058)\end{array}$ \\
\hline Age cubed/1000 & $\begin{array}{c}-0.002 \\
(0.010)\end{array}$ & $\begin{array}{c}-0.002 \\
(0.010)\end{array}$ & $\begin{array}{l}-0.005 \\
(0.020)\end{array}$ & $\begin{array}{c}0.003 \\
(0.009)\end{array}$ & $\begin{array}{l}-0.005 \\
(0.009)\end{array}$ & $\begin{array}{c}0.013^{* * *} \\
(0.004)\end{array}$ & $\begin{array}{c}0.013^{* * *} \\
(0.004)\end{array}$ & $\begin{array}{c}0.021^{* * *} \\
(0.007)\end{array}$ & $\begin{array}{c}0.006 \\
(0.005)\end{array}$ & $\begin{array}{l}0.009 * \\
(0.005)\end{array}$ \\
\hline Basic professional & $\begin{array}{c}0.019 \\
(0.033)\end{array}$ & $\begin{array}{c}0.019 \\
(0.033)\end{array}$ & $\begin{array}{c}0.031 \\
(0.070)\end{array}$ & $\begin{array}{c}0.005 \\
(0.031)\end{array}$ & $\begin{array}{c}0.001 \\
(0.025)\end{array}$ & $\begin{array}{c}0.040^{* *} \\
(0.020)\end{array}$ & $\begin{array}{c}0.040 * * \\
(0.020)\end{array}$ & $\begin{array}{c}0.078 * * \\
(0.032)\end{array}$ & $\begin{array}{c}0.007 \\
(0.020)\end{array}$ & $\begin{array}{l}0.041 * \\
(0.021)\end{array}$ \\
\hline Secondary general & $\begin{array}{c}0.074 * * \\
(0.031)\end{array}$ & $\begin{array}{c}0.074 * * \\
(0.031)\end{array}$ & $\begin{array}{c}0.177 * * * \\
(0.067)\end{array}$ & $\begin{array}{l}0.049 * \\
(0.029)\end{array}$ & $\begin{array}{l}0.040 * \\
(0.024)\end{array}$ & $\begin{array}{c}0.046^{* *} \\
(0.019)\end{array}$ & $\begin{array}{c}0.047^{* *} \\
(0.019)\end{array}$ & $\begin{array}{l}0.056^{*} \\
(0.030)\end{array}$ & $\begin{array}{c}0.040 * * \\
(0.020)\end{array}$ & $\begin{array}{c}0.012 \\
(0.021)\end{array}$ \\
\hline Secondary professional & $\begin{array}{c}0.083 * * \\
(0.034)\end{array}$ & $\begin{array}{c}0.084 * * \\
(0.034)\end{array}$ & $\begin{array}{c}0.212 * * * \\
(0.073)\end{array}$ & $\begin{array}{c}0.027 \\
(0.032)\end{array}$ & $\begin{array}{c}0.024 \\
(0.026)\end{array}$ & $\begin{array}{c}0.058 * * * \\
(0.021)\end{array}$ & $\begin{array}{c}0.059 * * * \\
(0.021)\end{array}$ & $\begin{array}{c}0.116^{* * *} \\
(0.033)\end{array}$ & $\begin{array}{l}0.040^{*} \\
(0.021)\end{array}$ & $\begin{array}{c}0.007 \\
(0.023)\end{array}$ \\
\hline Higher incomplete & $\begin{array}{c}0.174 * * * \\
(0.063)\end{array}$ & $\begin{array}{c}0.175^{* * *} \\
(0.063)\end{array}$ & $\begin{array}{c}0.322 * * \\
(0.159)\end{array}$ & $\begin{array}{c}0.162^{* *} \\
(0.072)\end{array}$ & $\begin{array}{c}0.074 \\
(0.055)\end{array}$ & $\begin{array}{c}0.064 \\
(0.040)\end{array}$ & $\begin{array}{c}0.064 \\
(0.040)\end{array}$ & $\begin{array}{c}0.075 \\
(0.067)\end{array}$ & $\begin{array}{c}0.051 \\
(0.050)\end{array}$ & $\begin{array}{c}0.041 \\
(0.051)\end{array}$ \\
\hline Higher & $\begin{array}{c}0.094 * * \\
(0.040)\end{array}$ & $\begin{array}{c}0.094 * * \\
(0.040)\end{array}$ & $\begin{array}{c}0.118 \\
(0.090)\end{array}$ & $\begin{array}{c}0.088^{* *} \\
(0.040)\end{array}$ & $\begin{array}{c}0.050 \\
(0.031)\end{array}$ & $\begin{array}{c}0.077 * * * \\
(0.024)\end{array}$ & $\begin{array}{c}0.076 * * * \\
(0.024)\end{array}$ & $\begin{array}{c}0.085^{* *} \\
(0.040)\end{array}$ & $\begin{array}{c}0.075^{* * *} \\
(0.026)\end{array}$ & $\begin{array}{c}0.062 * * \\
(0.027)\end{array}$ \\
\hline Single & $\begin{array}{c}0.028 \\
(0.077)\end{array}$ & $\begin{array}{c}0.028 \\
(0.077)\end{array}$ & $\begin{array}{c}-0.183 \\
(0.158)\end{array}$ & $\begin{array}{c}0.039 \\
(0.072)\end{array}$ & $\begin{array}{l}0.114^{*} \\
(0.060)\end{array}$ & $\begin{array}{c}-0.006 \\
(0.034)\end{array}$ & $\begin{array}{c}0.057 \\
(0.041)\end{array}$ & $\begin{array}{c}-0.034 \\
(0.057)\end{array}$ & $\begin{array}{l}-0.047 \\
(0.043)\end{array}$ & $\begin{array}{c}0.132 * * * \\
(0.042)\end{array}$ \\
\hline Divorced or widowed & $\begin{array}{c}0.012 \\
(0.032)\end{array}$ & $\begin{array}{c}0.012 \\
(0.032)\end{array}$ & $\begin{array}{c}0.097 \\
(0.084)\end{array}$ & $\begin{array}{l}-0.030 \\
(0.037)\end{array}$ & $\begin{array}{l}-0.015 \\
(0.030)\end{array}$ & $\begin{array}{c}-0.062 * * * \\
(0.021)\end{array}$ & $\begin{array}{c}-0.060 * * * \\
(0.021)\end{array}$ & $\begin{array}{l}-0.040 \\
(0.034)\end{array}$ & $\begin{array}{c}-0.062 * * * \\
(0.023)\end{array}$ & $\begin{array}{l}-0.022 \\
(0.024)\end{array}$ \\
\hline One child & $\begin{array}{l}-0.013 \\
(0.056)\end{array}$ & $\begin{array}{c}0.001 \\
(0.065)\end{array}$ & $\begin{array}{l}-0.135 \\
(0.121)\end{array}$ & $\begin{array}{c}0.024 \\
(0.054)\end{array}$ & $\begin{array}{c}0.042 \\
(0.045)\end{array}$ & $\begin{array}{c}0.037 \\
(0.028)\end{array}$ & $\begin{array}{c}0.120 * * * \\
(0.043)\end{array}$ & $\begin{array}{l}-0.027 \\
(0.054)\end{array}$ & $\begin{array}{c}0.045 \\
(0.037)\end{array}$ & $\begin{array}{l}0.072 * \\
(0.037)\end{array}$ \\
\hline More than one child & $\begin{array}{c}0.050 \\
(0.059)\end{array}$ & $\begin{array}{c}0.063 \\
(0.067)\end{array}$ & $\begin{array}{c}-0.034 \\
(0.129)\end{array}$ & $\begin{array}{l}0.098^{*} \\
(0.058)\end{array}$ & $\begin{array}{c}0.047 \\
(0.048)\end{array}$ & $\begin{array}{c}0.049 \\
(0.032)\end{array}$ & $\begin{array}{c}0.131 * * * \\
(0.045)\end{array}$ & $\begin{array}{l}-0.057 \\
(0.060)\end{array}$ & $\begin{array}{c}0.084 * * \\
(0.040)\end{array}$ & $\begin{array}{c}0.110 * * * \\
(0.041)\end{array}$ \\
\hline
\end{tabular}




\begin{tabular}{|c|c|c|c|c|c|c|c|c|c|c|}
\hline Training outside & $\begin{array}{c}0.175^{* * *} \\
(0.036)\end{array}$ & $\begin{array}{c}0.176^{* * *} \\
(0.036)\end{array}$ & $\begin{array}{c}0.033 \\
(0.099)\end{array}$ & $\begin{array}{c}0.185^{* * *} \\
(0.045)\end{array}$ & $\begin{array}{c}0.136^{* * * *} \\
(0.036)\end{array}$ & $\begin{array}{c}0.108 * * * \\
(0.025)\end{array}$ & $\begin{array}{c}0.107 * * * \\
(0.025)\end{array}$ & $\begin{array}{c}0.062 \\
(0.044)\end{array}$ & $\begin{array}{c}0.097 * * * \\
(0.028)\end{array}$ & $\begin{array}{l}0.056 * \\
(0.029)\end{array}$ \\
\hline \multirow[t]{2}{*}{ Mobility in the firm } & -0.019 & -0.019 & 0.035 & $-0.041^{*}$ & -0.023 & $-0.059 * * *$ & $-0.060 * * *$ & $-0.103^{* * *}$ & $-0.051 * * *$ & -0.011 \\
\hline & $(0.020)$ & $(0.020)$ & $(0.048)$ & $(0.021)$ & $(0.016)$ & $(0.013)$ & $(0.013)$ & $(0.023)$ & $(0.015)$ & $(0.016)$ \\
\hline Training in the firm & $\begin{array}{c}-0.063^{* * *} \\
(0.024)\end{array}$ & $\begin{array}{c}-0.063 * * * \\
(0.024)\end{array}$ & $\begin{array}{c}-0.106^{* *} \\
(0.053)\end{array}$ & $\begin{array}{l}-0.037 \\
(0.023)\end{array}$ & $\begin{array}{c}-0.061^{* * *} \\
(0.019)\end{array}$ & $\begin{array}{c}-0.172 * * * \\
(0.013)\end{array}$ & $\begin{array}{c}-0.170 * * * \\
(0.013)\end{array}$ & $\begin{array}{c}-0.180 * * * \\
(0.023)\end{array}$ & $\begin{array}{c}-0.197 * * * \\
(0.015)\end{array}$ & $\begin{array}{c}-0.124 * * * \\
(0.015)\end{array}$ \\
\hline Service staff & $\begin{array}{c}-0.759 * * * \\
(0.044)\end{array}$ & $\begin{array}{c}-0.759 * * * \\
(0.044)\end{array}$ & $\begin{array}{c}-0.747^{* * * *} \\
(0.097)\end{array}$ & $\begin{array}{c}-0.782^{* * *} \\
(0.043)\end{array}$ & $\begin{array}{c}-0.845^{* * *} \\
(0.035)\end{array}$ & $\begin{array}{c}-0.656^{* * * *} \\
(0.029)\end{array}$ & $\begin{array}{c}-0.654^{* * * *} \\
(0.029)\end{array}$ & $\begin{array}{c}-0.534 * * * \\
(0.041)\end{array}$ & $\begin{array}{c}-0.779 * * * \\
(0.027)\end{array}$ & $\begin{array}{c}-0.517 * * * \\
(0.028)\end{array}$ \\
\hline Engineers & $\begin{array}{c}-0.097^{* * *} * \\
(0.030)\end{array}$ & $\begin{array}{c}-0.097 * * * \\
(0.030)\end{array}$ & $\begin{array}{c}0.043 \\
(0.071)\end{array}$ & $\begin{array}{c}-0.106 * * * \\
(0.032)\end{array}$ & $\begin{array}{c}-0.170 * * * \\
(0.025)\end{array}$ & $\begin{array}{c}-0.074 * * * \\
(0.018)\end{array}$ & $\begin{array}{c}-0.072^{* * *} \\
(0.018)\end{array}$ & $\begin{array}{l}-0.014 \\
(0.033)\end{array}$ & $\begin{array}{c}-0.123^{* * *} \\
(0.021)\end{array}$ & $\begin{array}{c}0.003 \\
(0.022)\end{array}$ \\
\hline Accountants & $\begin{array}{c}0.335^{* * *} \\
(0.050)\end{array}$ & $\begin{array}{c}0.334 * * * \\
(0.050)\end{array}$ & $\begin{array}{c}0.635^{* * *} \\
(0.138)\end{array}$ & $\begin{array}{c}0.334 * * * \\
(0.064)\end{array}$ & $\begin{array}{c}0.022 \\
(0.050)\end{array}$ & $\begin{array}{l}0.063 * \\
(0.035)\end{array}$ & $\begin{array}{l}0.067 * \\
(0.035)\end{array}$ & $\begin{array}{c}0.080 \\
(0.072)\end{array}$ & $\begin{array}{c}0.055 \\
(0.044)\end{array}$ & $\begin{array}{c}0.128 * * * \\
(0.043)\end{array}$ \\
\hline Managers & $\begin{array}{c}0.598 * * * \\
(0.038)\end{array}$ & $\begin{array}{c}0.597 * * * \\
(0.038)\end{array}$ & $\begin{array}{c}0.930 * * * \\
(0.109)\end{array}$ & $\begin{array}{c}0.530 * * * \\
(0.054)\end{array}$ & $\begin{array}{c}0.434 * * * \\
(0.042)\end{array}$ & $\begin{array}{c}0.626 * * * \\
(0.023)\end{array}$ & $\begin{array}{c}0.628 * * * \\
(0.024)\end{array}$ & $\begin{array}{c}0.930 * * * \\
(0.051)\end{array}$ & $\begin{array}{c}0.546^{* * *} * \\
(0.036)\end{array}$ & $\begin{array}{c}0.564^{* * *} \\
(0.039)\end{array}$ \\
\hline Female*child & & $\begin{array}{c}-0.030 \\
(0.082)\end{array}$ & & & & & $\begin{array}{c}-0.108^{* *} \\
(0.043)\end{array}$ & & & \\
\hline Constant & $\begin{array}{c}-0.571 \\
(0.510)\end{array}$ & $\begin{array}{c}-0.598 \\
(0.519)\end{array}$ & $\begin{array}{l}-1.187 \\
(1.003)\end{array}$ & $\begin{array}{l}-0.892 * \\
(0.469)\end{array}$ & $\begin{array}{c}0.270 \\
(0.452)\end{array}$ & $\begin{array}{c}-1.164 * * * \\
(0.263)\end{array}$ & $\begin{array}{c}-1.257 * * * \\
(0.271)\end{array}$ & $\begin{array}{c}-1.975 * * * \\
(0.461)\end{array}$ & $\begin{array}{c}-0.765^{* *} \\
(0.297)\end{array}$ & $\begin{array}{l}-0.567 * \\
(0.290)\end{array}$ \\
\hline Observations & & & 2898 & & & & & 2974 & & \\
\hline R-squared & 0.34 & 0.34 & & & & 0.47 & 0.47 & & & \\
\hline
\end{tabular}

Notes: Robust standard errors in parentheses. * significant at $10 \%$;* significant at $5 \%$; *** significant at $1 \%$ 
Table 4 - Machado-Mata decompositions at quantiles: 1997 and 2002

\begin{tabular}{lccl}
\hline \hline Total gap & Characteristics & Coefficients & Quantiles \\
\hline .45133013 & .05959117 & $\mathbf{1 9 9 7}$ & 10 \\
.39865917 & .07281144 & .32584774 & 20 \\
.42273125 & .08751296 & .33521828 & 30 \\
.44319141 & .08621418 & .35697722 & 40 \\
.43860713 & .08154166 & .35706547 & 50 \\
.41059321 & .08013994 & .33045328 & 60 \\
.34895301 & .07761902 & .27133399 & 70 \\
.27671921 & .07339215 & .20332706 & 80 \\
.20676935 & .09197748 & .11479187 & 90 \\
\hline & & $\mathbf{2 0 0 2}$ & \\
\hline .02773124 & -.05076087 & .07849211 & 10 \\
.07009143 & -.03487897 & .1049704 & 20 \\
.12030653 & -.00410482 & .12441134 & 30 \\
.15570661 & .00364733 & .15205927 & 40 \\
.18806872 & .01494379 & .17312492 & 50 \\
.21567264 & .01650028 & .19917236 & 60 \\
.24022534 & .01897711 & .22124824 & 70 \\
.23481525 & .02055669 & .21425857 & 80 \\
.20537001 & .03721231 & .1681577 & 90 \\
\hline
\end{tabular}




\begin{tabular}{|c|c|c|c|}
\hline & Males & Females & "Gap \\
\hline Auxilliary 1 & n.a. & $\begin{array}{c}0.459 \\
(0.118) \\
{[1.00]}\end{array}$ & n.a. \\
\hline Auxilliary 2 & n.a. & $\begin{array}{l}0.642 \\
(0.218) \\
{[1.00]}\end{array}$ & n.a. \\
\hline Auxilliary 3 & $\begin{array}{c}0.738 \\
(0.172)\end{array}$ & $\begin{array}{c}0.726 \\
(0.143) \\
{[0.85]}\end{array}$ & $\begin{array}{c}0.012 \\
(0.029)\end{array}$ \\
\hline Auxilliary 4 & $\begin{array}{c}0.796 \\
(0.154)\end{array}$ & $\begin{array}{c}0.795 \\
(0.159) \\
{[0.90]}\end{array}$ & $\begin{array}{c}0.001 \\
(0.059)\end{array}$ \\
\hline Auxilliary 5 & $\begin{array}{c}1.028 \\
(0.147)\end{array}$ & $\begin{array}{l}1.020 \\
(0.128) \\
{[0.83]}\end{array}$ & $\begin{array}{c}0.008 \\
(0.021)\end{array}$ \\
\hline Auxilliary 6 & $\begin{array}{c}1.260 \\
(0.475)\end{array}$ & $\begin{array}{c}1.267 \\
(0.335) \\
{[0.67]}\end{array}$ & $\begin{array}{l}-0.007 \\
(0.324)\end{array}$ \\
\hline Primary 1 & $\begin{array}{c}0.466 \\
(0.075)\end{array}$ & $\begin{array}{l}\text { n.a. } \\
\text { [0] }\end{array}$ & n.a. \\
\hline Primary 2 & $\begin{array}{c}0.803 \\
(0.205)\end{array}$ & $\begin{array}{c}0.857 \\
(0.146) \\
{[0.04]}\end{array}$ & $\begin{array}{c}-0.054 \\
(0.065)\end{array}$ \\
\hline Primary 3 & $\begin{array}{c}1.053 \\
(0.248)\end{array}$ & $\begin{array}{c}1.143 \\
(0.207) \\
{[0.04]}\end{array}$ & $\begin{array}{l}-0.090 \\
(0.056)\end{array}$ \\
\hline Primary 4 & $\begin{array}{c}1.284 \\
(0.223)\end{array}$ & $\begin{array}{c}1.131 \\
(0.343) \\
{[0.08]}\end{array}$ & $\begin{array}{c}0.153^{* * * *} \\
(0.056)\end{array}$ \\
\hline Primary 5 & $\begin{array}{c}1.429 \\
(0.148)\end{array}$ & $\begin{array}{c}1.326 \\
(0.153) \\
{[0.03]}\end{array}$ & $\begin{array}{c}0.103^{*} \\
(0.062)\end{array}$ \\
\hline Primary 6 & $\begin{array}{c}1.605 \\
(0.153)\end{array}$ & $\begin{array}{l}\text { n.a. } \\
{[0]}\end{array}$ & n.a. \\
\hline Primary 7 & $\begin{array}{c}1.622 \\
(0.167)\end{array}$ & n.a. & n.a. \\
\hline Primary 8 & $\begin{array}{c}1.630 \\
(0.035)\end{array}$ & $\begin{array}{l}{[0]} \\
\text { n.a. } \\
{[0]}\end{array}$ & n.a. \\
\hline
\end{tabular}

Notes: Table shows means (standard deviations) of monthly wages in each level by gender, difference (standard errors) across gender and the proportion of women in each level [in square brackets]. * difference is significant at $10 \%$; *** difference is significant at $1 \%$. 
Table 6 - Probability for production workers to be in a primary level in 2002 and Fairlie decomposition

\begin{tabular}{|c|c|c|c|c|}
\hline \multirow[t]{2}{*}{$\begin{array}{l}\text { Total difference: } \\
\text { Explained part: }\end{array}$} & \multicolumn{4}{|c|}{$\begin{array}{c}0.836 \\
0.091 \\
{[10.89 \%]}\end{array}$} \\
\hline & \multicolumn{3}{|c|}{ Probit, marginal effects } & $\begin{array}{c}\text { Contribution } \\
\text { of: }\end{array}$ \\
\hline Female & $\begin{array}{c}-0.836^{* * *} \\
(0.017)\end{array}$ & $\begin{array}{c}-0.900^{* * * *} \\
(0.057)\end{array}$ & $\begin{array}{c}-0.923^{* * *} \\
(0.024)\end{array}$ & \\
\hline Tenure & $\begin{array}{c}0.005 \\
(0.013)\end{array}$ & $\begin{array}{c}0.005 \\
(0.014)\end{array}$ & $\begin{array}{l}-0.001 \\
(0.014)\end{array}$ & $\begin{array}{c}0.002 \\
(0.009)\end{array}$ \\
\hline Tenure squared /100 & $\begin{array}{l}0.242 * * \\
(0.116)\end{array}$ & $\begin{array}{c}0.239 * * \\
(0.117)\end{array}$ & $\begin{array}{c}0.303^{* *} \\
(0.123)\end{array}$ & $\begin{array}{c}0.176^{* * *} \\
(0.019)\end{array}$ \\
\hline Tenure cubed /1000 & $\begin{array}{c}-0.062 * * * \\
(0.024)\end{array}$ & $\begin{array}{c}-0.062 * * \\
(0.024)\end{array}$ & $\begin{array}{c}-0.073^{* * *} \\
(0.025)\end{array}$ & $\begin{array}{c}-0.152^{* * *} \\
(0.023)\end{array}$ \\
\hline Age & $\begin{array}{c}-0.121^{* *} \\
(0.056)\end{array}$ & $\begin{array}{c}-0.127 * * \\
(0.059)\end{array}$ & $\begin{array}{c}-0.117^{* *} \\
(0.058)\end{array}$ & $\begin{array}{c}0.388 * * * \\
(0.041)\end{array}$ \\
\hline Age squared /100 & $\begin{array}{c}0.288^{* *} \\
(0.140)\end{array}$ & $\begin{array}{l}0.301^{* *} \\
(0.147)\end{array}$ & $\begin{array}{l}0.277^{*} \\
(0.145)\end{array}$ & $\begin{array}{c}-0.140 * * * \\
(0.013)\end{array}$ \\
\hline Age cubed /1000 & $\begin{array}{c}-0.022 * * \\
(0.011)\end{array}$ & $\begin{array}{c}-0.023 * * \\
(0.012)\end{array}$ & $\begin{array}{l}-0.021 * \\
(0.012)\end{array}$ & $\begin{array}{c}-0.249 * * * \\
(0.035)\end{array}$ \\
\hline Basic professional & $\begin{array}{c}0.141 * * * \\
(0.032)\end{array}$ & $\begin{array}{c}0.142 * * * \\
(0.032)\end{array}$ & $\begin{array}{c}0.135^{* * * *} \\
(0.042)\end{array}$ & $\begin{array}{c}0.007 \\
(0.005)\end{array}$ \\
\hline Secondary general & $\begin{array}{c}0.260 * * * \\
(0.028)\end{array}$ & $\begin{array}{c}0.262 * * * \\
(0.028)\end{array}$ & $\begin{array}{c}0.253^{* * *} \\
(0.039)\end{array}$ & $\begin{array}{c}0.017 * * * \\
(0.004)\end{array}$ \\
\hline Secondary professional & $\begin{array}{c}0.184 * * * \\
(0.029)\end{array}$ & $\begin{array}{c}0.185^{* * *} \\
(0.030)\end{array}$ & $\begin{array}{c}0.170 * * * \\
(0.041)\end{array}$ & $\begin{array}{l}-0.002 \\
(0.002)\end{array}$ \\
\hline Higher incomplete & $\begin{array}{c}0.168 * * * \\
(0.030)\end{array}$ & $\begin{array}{c}0.168 * * * \\
(0.031)\end{array}$ & & \\
\hline Higher & $\begin{array}{c}0.188^{* * *} \\
(0.041)\end{array}$ & $\begin{array}{c}0.192 * * * \\
(0.041)\end{array}$ & $\begin{array}{c}0.023 \\
(0.089)\end{array}$ & $\begin{array}{c}0.00002 \\
(0.002)\end{array}$ \\
\hline Single & $\begin{array}{c}0.263 * * * \\
(0.028)\end{array}$ & $\begin{array}{c}0.268 * * * \\
(0.030)\end{array}$ & $\begin{array}{c}0.281 * * * \\
(0.029)\end{array}$ & $\begin{array}{c}0.050 * * \\
(0.020)\end{array}$ \\
\hline Divorced or widowed & $\begin{array}{c}0.120 * * * \\
(0.038)\end{array}$ & $\begin{array}{c}0.119 * * * \\
(0.039)\end{array}$ & $\begin{array}{c}0.127 * * * \\
(0.042)\end{array}$ & $\begin{array}{l}-0.002^{*} \\
(0.001)\end{array}$ \\
\hline One child & $\begin{array}{c}0.681 * * * \\
(0.099)\end{array}$ & $\begin{array}{c}0.667 * * * \\
(0.112)\end{array}$ & $\begin{array}{c}0.703 * * * \\
(0.089)\end{array}$ & $\begin{array}{c}0.029 * * \\
(0.012)\end{array}$ \\
\hline More than 1 child & $\begin{array}{c}0.324 * * * \\
(0.030)\end{array}$ & $\begin{array}{c}0.325^{* * *} \\
(0.033)\end{array}$ & $\begin{array}{c}0.346 * * * \\
(0.031)\end{array}$ & $\begin{array}{c}-0.031^{* *} \\
(0.014)\end{array}$ \\
\hline Training outside & $\begin{array}{c}0.208 * * * \\
(0.039)\end{array}$ & $\begin{array}{c}0.211 * * * \\
(0.040)\end{array}$ & $\begin{array}{c}0.224 * * * \\
(0.037)\end{array}$ & \\
\hline Mobility in the firm & $\begin{array}{c}-0.097^{* *} \\
(0.048)\end{array}$ & $\begin{array}{l}-0.094^{*} \\
(0.048)\end{array}$ & $\begin{array}{c}-0.101^{* *} \\
(0.051)\end{array}$ & $\begin{array}{l}-0.001 \\
(0.001)\end{array}$ \\
\hline Training in the firm & $\begin{array}{c}0.107 * * * \\
(0.031)\end{array}$ & $\begin{array}{c}0.105 * * * \\
(0.032)\end{array}$ & $\begin{array}{c}0.120 * * * \\
(0.033)\end{array}$ & \\
\hline Female*Child & & $\begin{array}{c}0.138 \\
(0.137)\end{array}$ & & \\
\hline Female* Basic professional & & & $\begin{array}{l}0.138 * \\
(0.073)\end{array}$ & \\
\hline Female* Secondary professional & & & $\begin{array}{c}0.167 * * * \\
(0.064)\end{array}$ & \\
\hline Female* Secondary general & & & $\begin{array}{c}0.177^{* * * *} \\
(0.062)\end{array}$ & \\
\hline Female*Higher & & & $\begin{array}{c}0.255^{* * *} \\
(0.021)\end{array}$ & \\
\hline Observations & 1876 & 1876 & 1861 & \\
\hline
\end{tabular}

Notes: Robust standard errors in parentheses. * significant at 10\%; ** significant at 5\%; *** significant at $1 \%$. 
Table 7 - Oaxaca-Blinder decompositions of production workers' earnings and total compensation with levels included: 2002

\begin{tabular}{lc}
\hline \hline & Monthly Wages \\
\hline Total difference & $0.228^{* * *}$ \\
& $(0.016)$ \\
Explained & $0.222^{* * *}$ \\
& $(0.025)$ \\
Unexplained & 0.007 \\
& $(0.026)$ \\
\hline \multicolumn{2}{c}{ Total compensation } \\
\hline Total difference & $0.196^{* * *}$ \\
& $(0.017)$ \\
Explained & $0.199 * * *$ \\
& $(0.028)$ \\
Unexplained & -0.003 \\
& $(0.028)$ \\
\hline
\end{tabular}

Table 8 - JMP decomposition of the change in the gender earnings differential: 1997-2002

\begin{tabular}{|c|c|c|}
\hline Decomposition & $\begin{array}{c}\text { Men as a } \\
\text { benchmark } \\
\text { group } \\
\end{array}$ & Pooled \\
\hline Total change in gender gap & \multicolumn{2}{|c|}{-0.199} \\
\hline Explained part & -0.057 & -0.057 \\
\hline [in \% of total] & [28.64\%] & {$[28.64 \%]$} \\
\hline due to: & & \\
\hline - observed characteristics (1) & -0.047 & -0.044 \\
\hline - observed prices (2) & -0.010 & -0.013 \\
\hline Unexplained part & -0.142 & -0.142 \\
\hline [in \% of total] & [71.36\% & {$[71.36 \%]$} \\
\hline \multicolumn{3}{|l|}{ due to: } \\
\hline - gap effect (3) & -0.062 & -0.054 \\
\hline - earnings dispersion / unobserved prices (4) & -0.080 & -0.089 \\
\hline Sum gender-specific: (1)+(3) & -0.109 & -0.098 \\
\hline Sum earnings structure: $(2)+(4)$ & -0.090 & -0.102 \\
\hline
\end{tabular}


Table 9 - Machado-Mata intertemporal counterfactuals: 1997 to 2002

\begin{tabular}{|c|c|c|c|c|c|}
\hline Gap & 10 & 25 & 50 & 75 & 90 \\
\hline $\begin{array}{l}\text { Actual: } \\
\text { (1) Gap actual } 2002^{1} \\
\text { (2) Gap actual } 1997^{1} \\
\text { (3) actual } 2002 / \text { actual } 1997 \\
\end{array}$ & $\begin{array}{l}0.060 \\
0.485 \\
0.124 \\
\end{array}$ & $\begin{array}{l}0.125 \\
0.375 \\
0.350 \\
\end{array}$ & $\begin{array}{l}0.196 \\
0.436 \\
0.450\end{array}$ & $\begin{array}{l}0.254 \\
0.322 \\
0.789 \\
\end{array}$ & $\begin{array}{l}0.216 \\
0.228 \\
0.947 \\
\end{array}$ \\
\hline $\begin{array}{l}\text { Counterfactual for women: } \\
\text { (4) Gap } 1=\beta^{m 02} X^{m 02}-\beta^{f 02} X^{f 97}\end{array}$ & 0.045 & 0.117 & 0.195 & 0.245 & 0.232 \\
\hline $\begin{array}{l}\text { (5) (4) / (2) } \\
\text { (6) (5) /(3) } \\
\text { (7) Gap } 2=\beta^{m 02} X^{m 02}-\beta^{f 97} X^{f 02}\end{array}$ & $\begin{array}{l}0.093 \\
0.750 \\
0.364\end{array}$ & $\begin{array}{l}0.328 \\
0.936 \\
0.238\end{array}$ & $\begin{array}{l}0.447 \\
0.995 \\
0.103\end{array}$ & $\begin{array}{c}0.761 \\
0.965 \\
-0.073\end{array}$ & $\begin{array}{r}1.018 \\
1.074 \\
-0.187\end{array}$ \\
\hline $\begin{array}{l}\text { (8) }(7) /(2) \\
\text { (9) }(8) /(3) \\
\text { Counterfactual for men: }\end{array}$ & $\begin{array}{l}0.751 \\
6.067\end{array}$ & $\begin{array}{l}0.667 \\
1.904\end{array}$ & $\begin{array}{l}0.236 \\
0.526\end{array}$ & $\begin{array}{l}-0.227 \\
-0.287\end{array}$ & $\begin{array}{l}-0.820 \\
-0.866\end{array}$ \\
\hline (10) Gap $3=\beta^{m 02} X^{m 97}-\beta^{f 02} X^{f 02}$ & 0.062 & 0.122 & 0.193 & 0.240 & 0.217 \\
\hline $\begin{array}{l}\text { (11) }(10) /(2) \\
(12)(11) /(3)\end{array}$ & $\begin{array}{l}0.128 \\
1.033 \\
0.102\end{array}$ & $\begin{array}{l}0.342 \\
0.976 \\
0.291\end{array}$ & $\begin{array}{l}0.443 \\
0.985 \\
0.498\end{array}$ & $\begin{array}{l}0.745 \\
0.945 \\
0.608\end{array}$ & $\begin{array}{l}0.952 \\
1.005 \\
0.620\end{array}$ \\
\hline $\begin{array}{l}\text { (13) Gap } 4=\beta 3 \\
\text { (14) (13) / (2) } \\
\text { (15) }(14) /(3)\end{array}$ & $\begin{array}{l}0.210 \\
1.700\end{array}$ & $\begin{array}{l}0.815 \\
2.328 \\
\end{array}$ & $\begin{array}{l}1.142 \\
2.541 \\
\end{array}$ & $\begin{array}{l}1.888 \\
2.394 \\
\end{array}$ & $\begin{array}{l}2.719 \\
2.870 \\
\end{array}$ \\
\hline
\end{tabular}

Note: ${ }^{1}$ The actual gap is the coefficient on the male dummy in the quantile regressions without covariates.

Table 10 - Oaxaca-Blinder decompositions of earnings for whole sample (including those with wage arrears) and those paid in full: 1998

\begin{tabular}{|c|c|c|}
\hline & Whole sample & Paid in full \\
\hline & \multicolumn{2}{|c|}{ All employess } \\
\hline Total differential & $\begin{array}{c}0.386 * * * \\
(0.017)\end{array}$ & $\begin{array}{c}0.444 * * * \\
(0.032)\end{array}$ \\
\hline Unexplained gap & $\begin{array}{c}0.276 * * * \\
(0.017) \\
{[71.50 \%]}\end{array}$ & $\begin{array}{c}0.355 * * * \\
(0.032) \\
{[79.95 \%]}\end{array}$ \\
\hline Total differential & $\begin{array}{c}0.461^{* * *} \\
(0.023)\end{array}$ & $\begin{array}{c}0.445^{* * *} \\
(0.032)\end{array}$ \\
\hline Unexplained gap & $\begin{array}{c}0.409 * * * \\
(0.023) \\
{[88.72 \%]}\end{array}$ & $\begin{array}{c}0.353 * * * \\
(0.033) \\
{[79.33 \%]}\end{array}$ \\
\hline
\end{tabular}


Table 11 - Probability of separations, pooled 1997-2002: Probit marginal effects

\begin{tabular}{|c|c|c|}
\hline & (1) & (2) \\
\hline Female & $\begin{array}{c}0.248^{* * *} \\
(0.031)\end{array}$ & $\begin{array}{c}0.167 * * * \\
(0.048)\end{array}$ \\
\hline Female*child & & $\begin{array}{c}0.082 * * \\
(0.039)\end{array}$ \\
\hline Tenure & $\begin{array}{c}-0.004 \\
(0.004)\end{array}$ & $\begin{array}{c}-0.004 \\
(0.004)\end{array}$ \\
\hline Tenure squared /100 & $\begin{array}{c}0.009 \\
(0.032)\end{array}$ & $\begin{array}{c}0.008 \\
(0.032)\end{array}$ \\
\hline Tenure cubed/1000 & $\begin{array}{l}-0.005 \\
(0.007)\end{array}$ & $\begin{array}{l}-0.005 \\
(0.007)\end{array}$ \\
\hline Age & $\begin{array}{c}0.098 * * * \\
(0.020)\end{array}$ & $\begin{array}{c}0.094 * * * \\
(0.020)\end{array}$ \\
\hline Age squared/100 & $\begin{array}{c}-0.312^{* * *} \\
(0.051)\end{array}$ & $\begin{array}{c}-0.303 * * * \\
(0.051)\end{array}$ \\
\hline Age cubed/1000 & $\begin{array}{c}0.030 * * * \\
(0.004)\end{array}$ & $\begin{array}{c}0.029 * * * \\
(0.004)\end{array}$ \\
\hline Basic professional & $\begin{array}{c}0.309 * * * \\
(0.017)\end{array}$ & $\begin{array}{c}0.309 * * * \\
(0.017)\end{array}$ \\
\hline Secondary general & $\begin{array}{c}0.035^{* *} \\
(0.014)\end{array}$ & $\begin{array}{c}0.035^{* *} \\
(0.014)\end{array}$ \\
\hline Secondary professional & $\begin{array}{c}0.206 * * * \\
(0.016)\end{array}$ & $\begin{array}{c}0.206 * * * \\
(0.016)\end{array}$ \\
\hline Higher incomplete & $\begin{array}{c}0.281 * * * \\
(0.034)\end{array}$ & $\begin{array}{c}0.280 * * * \\
(0.034)\end{array}$ \\
\hline Higher & $\begin{array}{c}0.207 * * * \\
(0.021)\end{array}$ & $\begin{array}{c}0.206^{* * *} \\
(0.021)\end{array}$ \\
\hline Single & $\begin{array}{c}-0.175^{* * *} \\
(0.019)\end{array}$ & $\begin{array}{c}-0.182 * * * \\
(0.017)\end{array}$ \\
\hline Divorced or widowed & $\begin{array}{c}-0.083^{* * *} \\
(0.015)\end{array}$ & $\begin{array}{c}-0.084 * * * \\
(0.015)\end{array}$ \\
\hline One child & $\begin{array}{c}-0.371 * * * \\
(0.030)\end{array}$ & $\begin{array}{c}-0.418 * * * \\
(0.035)\end{array}$ \\
\hline More than one child & $\begin{array}{c}-0.249 * * * \\
(0.015)\end{array}$ & $\begin{array}{c}-0.269 * * * \\
(0.015)\end{array}$ \\
\hline Training outside & $\begin{array}{c}-0.018 \\
(0.024)\end{array}$ & $\begin{array}{c}-0.018 \\
(0.024)\end{array}$ \\
\hline Mobility in the firm & $\begin{array}{c}-0.109 * * * \\
(0.009)\end{array}$ & $\begin{array}{c}-0.108 * * * \\
(0.009)\end{array}$ \\
\hline Training in the firm & $\begin{array}{l}-0.001 \\
(0.010)\end{array}$ & $\begin{array}{c}-0.001 \\
(0.010)\end{array}$ \\
\hline Service staff & $\begin{array}{c}-0.220^{* * *} \\
(0.009)\end{array}$ & $\begin{array}{c}-0.220 * * * \\
(0.009)\end{array}$ \\
\hline Engineers & $\begin{array}{c}-0.314^{* * *} \\
(0.010)\end{array}$ & $\begin{array}{c}-0.313 * * * \\
(0.010)\end{array}$ \\
\hline Managers & $\begin{array}{c}-0.178 * * * \\
(0.015)\end{array}$ & $\begin{array}{c}-0.177 * * * \\
(0.015)\end{array}$ \\
\hline Accountants & $\begin{array}{c}-0.042 \\
(0.027)\end{array}$ & $\begin{array}{l}-0.041 \\
(0.027)\end{array}$ \\
\hline 1998 & $\begin{array}{c}0.037 * * * \\
(0.012)\end{array}$ & $\begin{array}{c}0.037 * * * \\
(0.012)\end{array}$ \\
\hline 1999 & $\begin{array}{c}-0.036 * * * \\
(0.011)\end{array}$ & $\begin{array}{c}-0.036 * * * \\
(0.011)\end{array}$ \\
\hline 2000 & $\begin{array}{c}-0.095^{* * *} \\
(0.011)\end{array}$ & $\begin{array}{c}-0.095 * * * \\
(0.011)\end{array}$ \\
\hline 2001 & $\begin{array}{c}-0.137 * * * \\
(0.011)\end{array}$ & $\begin{array}{c}-0.137 * * * \\
(0.011)\end{array}$ \\
\hline 1st decile & $0.232 * * *$ & $0.233^{* * *}$ \\
\hline
\end{tabular}




\begin{tabular}{|c|c|c|}
\hline & $(0.032)$ & $(0.032)$ \\
\hline \multirow[t]{2}{*}{ 2nd decile } & $0.218 * * *$ & $0.218 * * *$ \\
\hline & $(0.030)$ & $(0.030)$ \\
\hline \multirow[t]{2}{*}{ 3rd decile } & $0.212 * * *$ & $0.212 * * *$ \\
\hline & $(0.028)$ & $(0.028)$ \\
\hline \multirow[t]{2}{*}{ 4th decile } & $0.119 * * *$ & $0.119 * * *$ \\
\hline & $(0.028)$ & $(0.028)$ \\
\hline \multirow[t]{2}{*}{ 6th decile } & $0.085 * * *$ & $0.085 * * *$ \\
\hline & $(0.027)$ & $(0.027)$ \\
\hline \multirow[t]{2}{*}{ 7th decile } & 0.018 & 0.018 \\
\hline & $(0.023)$ & $(0.023)$ \\
\hline \multirow[t]{2}{*}{ 8th decile } & $0.056 * *$ & $0.056 * *$ \\
\hline & $(0.022)$ & $(0.022)$ \\
\hline \multirow[t]{2}{*}{ 9th decile } & $0.127 * * *$ & $0.127 * * *$ \\
\hline & $(0.029)$ & $(0.029)$ \\
\hline \multirow[t]{2}{*}{ 10th decile } & $0.169 * * *$ & $0.171 * * *$ \\
\hline & $(0.026)$ & $(0.026)$ \\
\hline \multirow[t]{2}{*}{ female* 1 st decile } & $-0.196 * * *$ & $-0.196 * * *$ \\
\hline & $(0.019)$ & $(0.019)$ \\
\hline \multirow[t]{2}{*}{ female* 2nd decile } & $-0.176^{* * *}$ & $-0.176 * * *$ \\
\hline & $(0.021)$ & $(0.021)$ \\
\hline \multirow[t]{2}{*}{ female* 3rd decile } & $-0.194 * * *$ & $-0.194 * * *$ \\
\hline & $(0.019)$ & $(0.019)$ \\
\hline \multirow[t]{2}{*}{ female* 4 th decile } & $-0.142 * * *$ & $-0.140 * * *$ \\
\hline & $(0.027)$ & $(0.027)$ \\
\hline \multirow[t]{2}{*}{ female* 6th decile } & -0.000 & 0.001 \\
\hline & $(0.040)$ & $(0.040)$ \\
\hline \multirow[t]{2}{*}{ female* 7 th decile } & -0.049 & -0.050 \\
\hline & $(0.035)$ & $(0.035)$ \\
\hline \multirow[t]{2}{*}{ female* 8th decile } & $-0.067 * *$ & $-0.067 * *$ \\
\hline & $(0.034)$ & $(0.034)$ \\
\hline \multirow[t]{2}{*}{ female* 9th decile } & $-0.167 * * *$ & $-0.167 * * *$ \\
\hline & $(0.025)$ & $(0.024)$ \\
\hline \multirow[t]{2}{*}{ female* 10 th decile } & $-0.176 * * *$ & $-0.177 * * *$ \\
\hline & $(0.022)$ & $(0.022)$ \\
\hline Observations & & \\
\hline
\end{tabular}

Notes: Robust standard errors in parentheses. * significant at $10 \%$; ** significant at $5 \%$; *** significant at $1 \%$. Deciles given are deciles in employee category specific wage distributions. 


\section{APPENDIX}

Table A1 - OLS and quantile regressions by gender, 1997

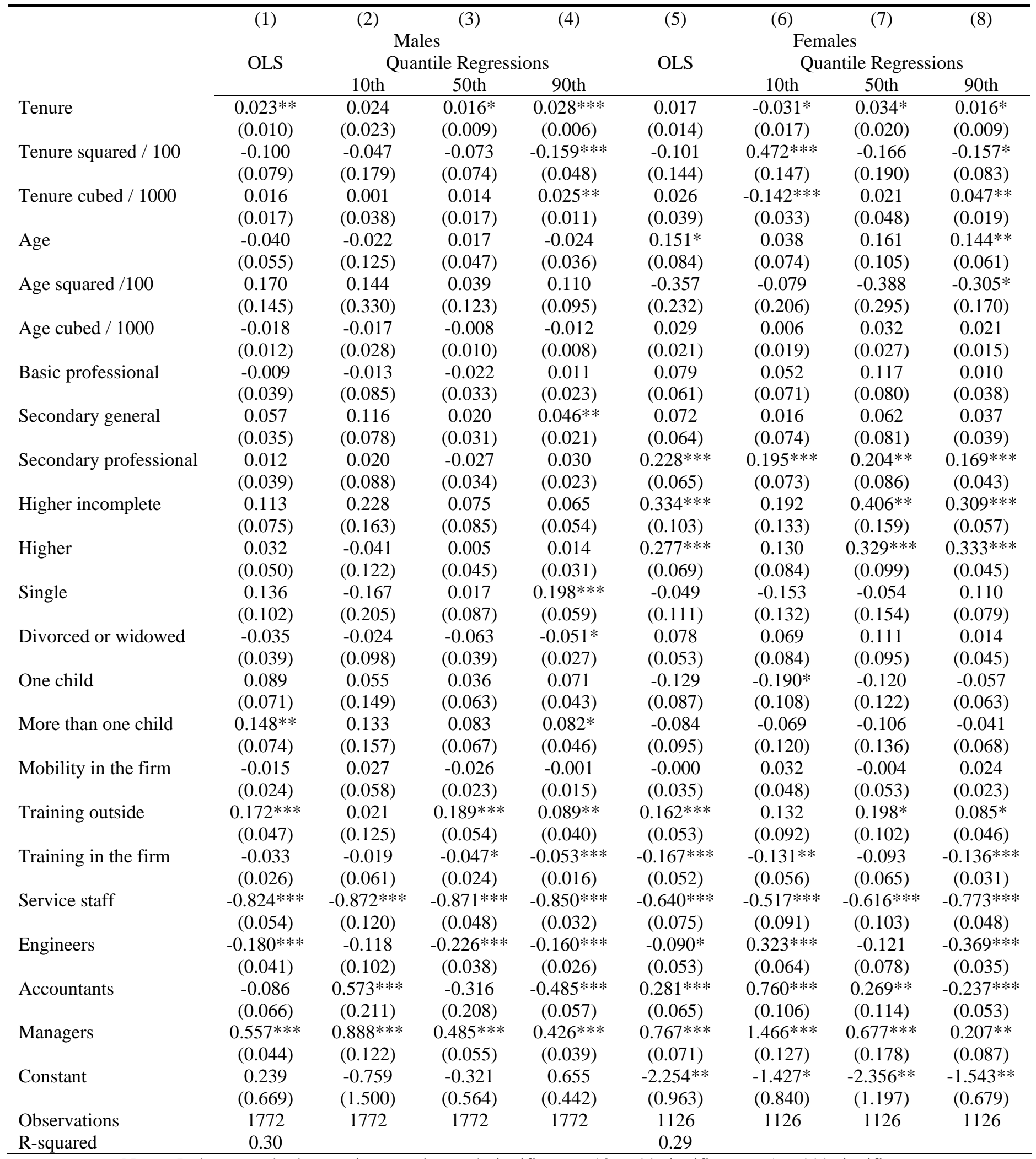

Notes: Robust standard errors in parentheses. * significant at 10\%; ** significant at 5\%; *** significant at $1 \%$. 
Table A2 - OLS and quantile regressions by gender, 2002

\begin{tabular}{|c|c|c|c|c|c|c|c|c|}
\hline & (1) & (2) & (3) & (4) & (5) & (6) & (7) & (8) \\
\hline & \multicolumn{4}{|c|}{ Males } & \multirow{2}{*}{\multicolumn{4}{|c|}{$\begin{array}{l}\text { Females } \\
\text { Quantile Regressions }\end{array}$}} \\
\hline & \multirow[t]{2}{*}{ OLS } & \multicolumn{3}{|c|}{ Quantile Regressions } & & & & \\
\hline & & 10th & 50th & 90th & & 10th & 50th & 90th \\
\hline Tenure & $\begin{array}{c}0.026^{* * *} \\
(0.008)\end{array}$ & $\begin{array}{c}0.039^{* * *} \\
(0.012)\end{array}$ & $\begin{array}{l}0.012^{* *} \\
(0.006)\end{array}$ & $\begin{array}{c}0.018^{* * *} \\
(0.006)\end{array}$ & $\begin{array}{l}-0.001 \\
(0.008)\end{array}$ & $\begin{array}{l}-0.016 \\
(0.012)\end{array}$ & $\begin{array}{l}-0.013^{*} \\
(0.008)\end{array}$ & $\begin{array}{c}0.003 \\
(0.010)\end{array}$ \\
\hline Tenure squared /100 & $\begin{array}{c}-0.130 * * * \\
(0.050)\end{array}$ & $\begin{array}{c}-0.228^{* * *} \\
(0.083)\end{array}$ & $\begin{array}{l}-0.060 \\
(0.040)\end{array}$ & $\begin{array}{c}-0.095^{* *} \\
(0.039)\end{array}$ & $\begin{array}{c}0.031 \\
(0.073)\end{array}$ & $\begin{array}{c}0.133 \\
(0.088)\end{array}$ & $\begin{array}{l}0.136 * * \\
(0.064)\end{array}$ & $\begin{array}{c}0.022 \\
(0.088)\end{array}$ \\
\hline Tenure cubed /1000 & $\begin{array}{c}0.023^{* * *} \\
(0.009)\end{array}$ & $\begin{array}{c}0.044^{* * *} \\
(0.017)\end{array}$ & $\begin{array}{c}0.011 \\
(0.008)\end{array}$ & $\begin{array}{c}0.015^{* *} \\
(0.007)\end{array}$ & $\begin{array}{l}-0.003 \\
(0.018)\end{array}$ & $\begin{array}{l}-0.028 \\
(0.019)\end{array}$ & $\begin{array}{c}-0.029^{* *} \\
(0.015)\end{array}$ & $\begin{array}{c}-0.001 \\
(0.021)\end{array}$ \\
\hline Age & $\begin{array}{c}0.090 * * * \\
(0.029)\end{array}$ & $\begin{array}{c}0.057 \\
(0.054)\end{array}$ & $\begin{array}{c}0.091 * * * \\
(0.027)\end{array}$ & $\begin{array}{c}0.033 \\
(0.024)\end{array}$ & $\begin{array}{c}0.013 \\
(0.031)\end{array}$ & $\begin{array}{c}0.059 \\
(0.065)\end{array}$ & $\begin{array}{l}-0.024 \\
(0.039)\end{array}$ & $\begin{array}{c}0.033 \\
(0.036)\end{array}$ \\
\hline Age squared /100 & $\begin{array}{c}-0.196 * * * \\
(0.070)\end{array}$ & $\begin{array}{l}-0.115 \\
(0.134)\end{array}$ & $\begin{array}{c}-0.172 * * * \\
(0.066)\end{array}$ & $\begin{array}{l}-0.058 \\
(0.061)\end{array}$ & $\begin{array}{l}-0.015 \\
(0.079)\end{array}$ & $\begin{array}{l}-0.136 \\
(0.163)\end{array}$ & $\begin{array}{c}0.068 \\
(0.101)\end{array}$ & $\begin{array}{l}-0.081 \\
(0.094)\end{array}$ \\
\hline Age cubed /1000 & $\begin{array}{c}0.014^{* *} \\
(0.006)\end{array}$ & $\begin{array}{c}0.008 \\
(0.011)\end{array}$ & $\begin{array}{l}0.011^{* *} \\
(0.005)\end{array}$ & $\begin{array}{c}0.004 \\
(0.005)\end{array}$ & $\begin{array}{c}0.000 \\
(0.007)\end{array}$ & $\begin{array}{c}0.010 \\
(0.013)\end{array}$ & $\begin{array}{l}-0.006 \\
(0.008)\end{array}$ & $\begin{array}{c}0.006 \\
(0.008)\end{array}$ \\
\hline Basic professional & $\begin{array}{l}0.050^{*} \\
(0.028)\end{array}$ & $\begin{array}{l}0.110^{* * *} \\
(0.047)\end{array}$ & $\begin{array}{c}0.000 \\
(0.023)\end{array}$ & $\begin{array}{c}0.036 \\
(0.022)\end{array}$ & $\begin{array}{c}0.002 \\
(0.025)\end{array}$ & $\begin{array}{c}0.010 \\
(0.047)\end{array}$ & $\begin{array}{l}-0.009 \\
(0.029)\end{array}$ & $\begin{array}{c}-0.042 \\
(0.035)\end{array}$ \\
\hline Secondary general & $\begin{array}{c}0.025 \\
(0.026)\end{array}$ & $\begin{array}{c}0.053 \\
(0.041)\end{array}$ & $\begin{array}{l}-0.002 \\
(0.022)\end{array}$ & $\begin{array}{l}-0.021 \\
(0.022)\end{array}$ & $\begin{array}{c}0.066^{* *} \\
(0.030)\end{array}$ & $\begin{array}{c}0.024 \\
(0.047)\end{array}$ & $\begin{array}{c}0.033 \\
(0.030)\end{array}$ & $\begin{array}{c}0.033 \\
(0.036)\end{array}$ \\
\hline Secondary professional & $\begin{array}{c}0.027 \\
(0.029)\end{array}$ & $\begin{array}{l}0.081^{*} \\
(0.047)\end{array}$ & $\begin{array}{c}0.008 \\
(0.024)\end{array}$ & $\begin{array}{l}-0.033 \\
(0.024)\end{array}$ & $\begin{array}{c}0.098^{* * *} \\
(0.027)\end{array}$ & $\begin{array}{c}0.133^{* * *} \\
(0.050)\end{array}$ & $\begin{array}{l}0.057^{*} \\
(0.031)\end{array}$ & $\begin{array}{c}0.033 \\
(0.036)\end{array}$ \\
\hline Higher incomplete & $\begin{array}{c}0.032 \\
(0.064)\end{array}$ & $\begin{array}{c}0.036 \\
(0.120)\end{array}$ & $\begin{array}{c}0.019 \\
(0.062)\end{array}$ & $\begin{array}{c}0.021 \\
(0.048)\end{array}$ & $\begin{array}{c}0.110 * * \\
(0.047)\end{array}$ & $\begin{array}{l}0.192 * * \\
(0.094)\end{array}$ & $\begin{array}{c}0.035 \\
(0.063)\end{array}$ & $\begin{array}{c}0.044 \\
(0.070)\end{array}$ \\
\hline Higher & $\begin{array}{c}0.043 \\
(0.033)\end{array}$ & $\begin{array}{c}0.029 \\
(0.061)\end{array}$ & $\begin{array}{c}0.018 \\
(0.031)\end{array}$ & $\begin{array}{l}-0.028 \\
(0.028)\end{array}$ & $\begin{array}{c}0.141^{* * *} \\
(0.033)\end{array}$ & $\begin{array}{l}0.136^{* *} \\
(0.061)\end{array}$ & $\begin{array}{c}0.084^{* *} \\
(0.036)\end{array}$ & $\begin{array}{c}0.168 * * * \\
(0.043)\end{array}$ \\
\hline Single & $\begin{array}{c}0.194 * * * \\
(0.068)\end{array}$ & $\begin{array}{c}0.037 \\
(0.151)\end{array}$ & $\begin{array}{c}0.246 * * * \\
(0.081)\end{array}$ & $\begin{array}{c}0.069 \\
(0.076)\end{array}$ & $\begin{array}{l}-0.020 \\
(0.042)\end{array}$ & $\begin{array}{c}0.026 \\
(0.085)\end{array}$ & $\begin{array}{c}0.023 \\
(0.055)\end{array}$ & $\begin{array}{c}0.073 \\
(0.057)\end{array}$ \\
\hline Divorced or widowed & $\begin{array}{c}-0.065^{* * *} \\
(0.025)\end{array}$ & $\begin{array}{l}-0.029 \\
(0.048)\end{array}$ & $\begin{array}{c}-0.108 * * * \\
(0.026)\end{array}$ & $\begin{array}{l}-0.050^{*} \\
(0.026)\end{array}$ & $\begin{array}{c}-0.042 \\
(0.036)\end{array}$ & $\begin{array}{l}-0.060 \\
(0.049)\end{array}$ & $\begin{array}{l}-0.020 \\
(0.032)\end{array}$ & $\begin{array}{c}0.016 \\
(0.037)\end{array}$ \\
\hline One child & $\begin{array}{c}0.221^{* * *} \\
(0.059)\end{array}$ & $\begin{array}{c}0.067 \\
(0.137)\end{array}$ & $\begin{array}{c}0.315^{* * *} \\
(0.074)\end{array}$ & $\begin{array}{c}0.050 \\
(0.071)\end{array}$ & $\begin{array}{c}0.054 \\
(0.036)\end{array}$ & $\begin{array}{c}0.045 \\
(0.066)\end{array}$ & $\begin{array}{c}0.129 * * * \\
(0.042)\end{array}$ & $\begin{array}{c}0.124 * * \\
(0.052)\end{array}$ \\
\hline More than one child & $\begin{array}{c}0.211^{* * *} \\
(0.061)\end{array}$ & $\begin{array}{c}0.028 \\
(0.140)\end{array}$ & $\begin{array}{c}0.331^{* * *} \\
(0.075)\end{array}$ & $\begin{array}{c}0.067 \\
(0.073)\end{array}$ & $\begin{array}{c}0.090^{* *} \\
(0.042)\end{array}$ & $\begin{array}{c}0.027 \\
(0.075)\end{array}$ & $\begin{array}{c}0.156^{* * *} \\
(0.048)\end{array}$ & $\begin{array}{c}0.157 * * * \\
(0.058)\end{array}$ \\
\hline Mobility in the firm & $\begin{array}{c}-0.061 * * * \\
(0.017)\end{array}$ & $\begin{array}{c}-0.081^{* *} \\
(0.033)\end{array}$ & $\begin{array}{c}-0.056 * * * \\
(0.017)\end{array}$ & $\begin{array}{l}-0.021 \\
(0.016)\end{array}$ & $\begin{array}{c}-0.048^{* *} \\
(0.021)\end{array}$ & $\begin{array}{c}-0.099 * * * \\
(0.036)\end{array}$ & $\begin{array}{l}-0.017 \\
(0.021)\end{array}$ & $\begin{array}{c}0.022 \\
(0.027)\end{array}$ \\
\hline Training outside & $\begin{array}{c}0.131^{* * *} \\
(0.027)\end{array}$ & $\begin{array}{c}0.060 \\
(0.059)\end{array}$ & $\begin{array}{c}0.104 * * * \\
(0.034)\end{array}$ & $\begin{array}{l}0.075^{* *} \\
(0.035)\end{array}$ & $\begin{array}{l}0.088^{*} \\
(0.047)\end{array}$ & $\begin{array}{c}0.089 \\
(0.061)\end{array}$ & $\begin{array}{c}0.138 * * * \\
(0.038)\end{array}$ & $\begin{array}{c}0.027 \\
(0.039)\end{array}$ \\
\hline Training in the firm & $\begin{array}{c}-0.157^{* * *} \\
(0.016)\end{array}$ & $\begin{array}{c}-0.197 * * * \\
(0.032)\end{array}$ & $\begin{array}{c}-0.148^{* * * *} \\
(0.016)\end{array}$ & $\begin{array}{c}-0.117^{* * *} \\
(0.015)\end{array}$ & $\begin{array}{c}-0.210^{* * *} \\
(0.022)\end{array}$ & $\begin{array}{c}-0.193^{* * * *} \\
(0.037)\end{array}$ & $\begin{array}{c}-0.288^{* * *} \\
(0.024)\end{array}$ & $\begin{array}{l}-0.155^{* * *} \\
(0.028)\end{array}$ \\
\hline Service staff & $\begin{array}{c}-0.686^{* * *} \\
(0.041)\end{array}$ & $\begin{array}{c}-0.589 * * * \\
(0.057)\end{array}$ & $\begin{array}{c}-0.845 * * * \\
(0.030)\end{array}$ & $\begin{array}{c}-0.413^{* * * *} \\
(0.028)\end{array}$ & $\begin{array}{c}-0.578 * * * \\
(0.030)\end{array}$ & $\begin{array}{c}-0.438 * * * \\
(0.064)\end{array}$ & $\begin{array}{c}-0.672^{* * *} \\
(0.042)\end{array}$ & $\begin{array}{c}-0.673 * * * \\
(0.049)\end{array}$ \\
\hline Engineers & $\begin{array}{c}-0.125^{* * *} \\
(0.024)\end{array}$ & $\begin{array}{l}-0.055 \\
(0.049)\end{array}$ & $\begin{array}{c}-0.164 * * * \\
(0.025)\end{array}$ & $\begin{array}{c}-0.056^{* *} \\
(0.023)\end{array}$ & $\begin{array}{l}-0.022 \\
(0.026)\end{array}$ & $\begin{array}{c}0.004 \\
(0.049)\end{array}$ & $\begin{array}{c}-0.082 * * * \\
(0.030)\end{array}$ & $\begin{array}{c}0.030 \\
(0.035)\end{array}$ \\
\hline Accountants & $\begin{array}{c}-0.181 * * * \\
(0.037)\end{array}$ & $\begin{array}{l}0.225^{*} \\
(0.116)\end{array}$ & $\begin{array}{c}-0.286^{* *} \\
(0.143)\end{array}$ & $\begin{array}{c}-0.416^{* * *} \\
(0.054)\end{array}$ & $\begin{array}{c}0.065 \\
(0.042)\end{array}$ & $\begin{array}{c}0.091 \\
(0.081)\end{array}$ & $\begin{array}{c}0.014 \\
(0.046)\end{array}$ & $\begin{array}{c}0.024 \\
(0.052)\end{array}$ \\
\hline Managers & $\begin{array}{c}0.582 * * * \\
(0.027)\end{array}$ & $\begin{array}{c}0.887 * * * \\
(0.069)\end{array}$ & $\begin{array}{c}0.511 * * * \\
(0.037)\end{array}$ & $\begin{array}{c}0.442 * * * \\
(0.037)\end{array}$ & $\begin{array}{c}0.782 * * * \\
(0.035)\end{array}$ & $\begin{array}{c}1.032 * * * \\
(0.096)\end{array}$ & $\begin{array}{c}0.754 * * * \\
(0.062)\end{array}$ & $\begin{array}{c}0.596 * * * \\
(0.078)\end{array}$ \\
\hline Constant & $\begin{array}{c}-1.540 * * * \\
(0.367)\end{array}$ & $\begin{array}{c}-1.398^{* *} \\
(0.711)\end{array}$ & $\begin{array}{c}-1.650 * * * \\
(0.348)\end{array}$ & $\begin{array}{l}-0.284 \\
(0.310)\end{array}$ & $\begin{array}{l}-0.428 \\
(0.384)\end{array}$ & $\begin{array}{l}-1.209 \\
(0.819)\end{array}$ & $\begin{array}{c}0.130 \\
(0.483)\end{array}$ & $\begin{array}{l}-0.440 \\
(0.442)\end{array}$ \\
\hline $\begin{array}{l}\text { Observations } \\
\text { R-squared }\end{array}$ & $\begin{array}{l}1853 \\
0.46 \\
\end{array}$ & 1853 & 1853 & 1853 & $\begin{array}{l}1121 \\
0.48\end{array}$ & 1121 & 1121 & 1121 \\
\hline
\end{tabular}

Notes: Robust standard errors in parentheses. * significant at $10 \%$; ** significant at $5 \%$; *** significant at $1 \%$. 